\title{
(10) Nordregio
}

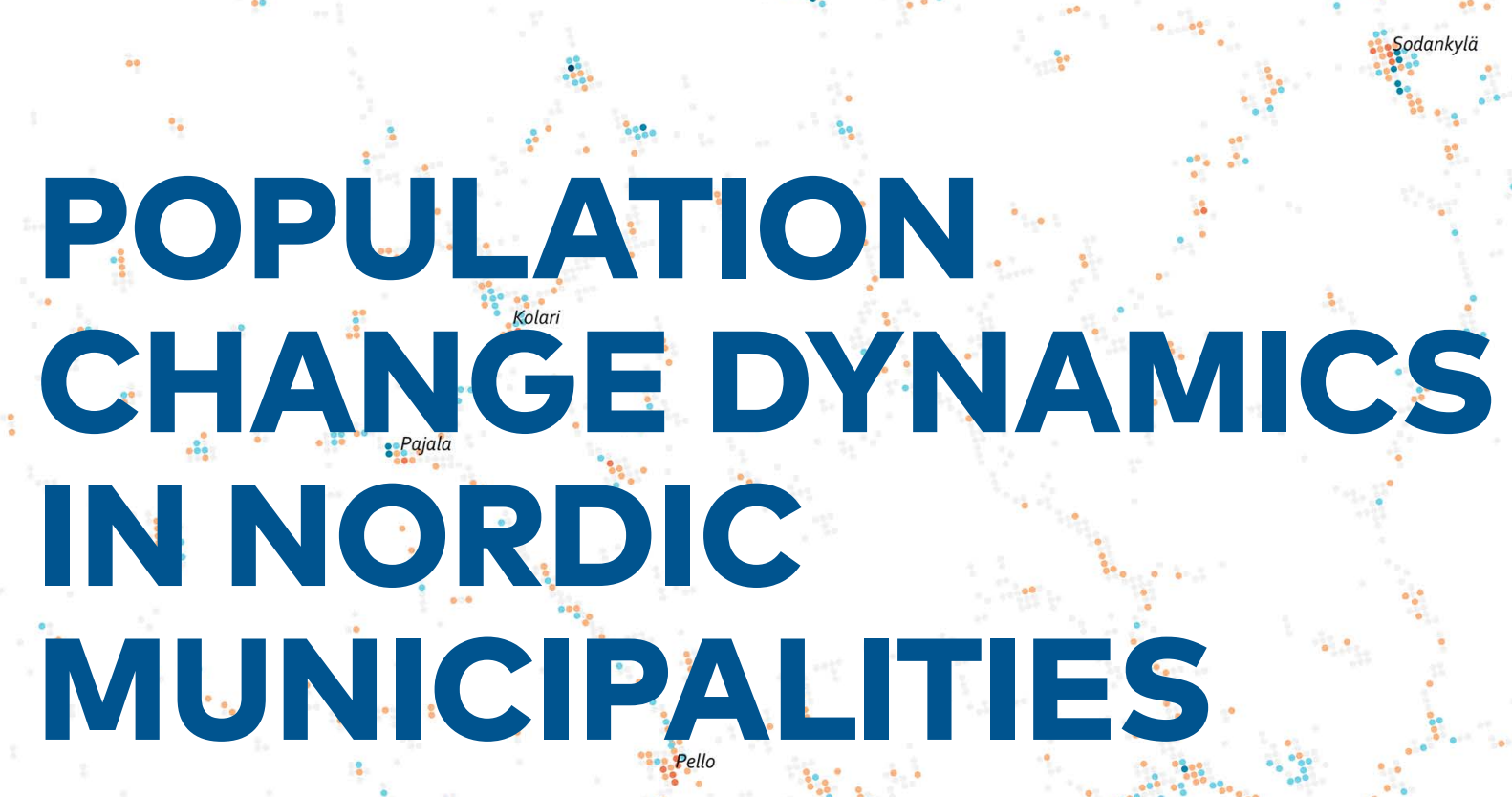

- grid data as a tool for studying residential change at local level

Mats Stjęrnberg \& Oskar Penje N้ORDREGIO REPORT 2019:1 Edition 2 



\section{POPULATION CHANGE DYNAMICS IN NORDIC MUNICIPALITIES \\ - grid data as a tool for studying residential change at local level}

Mats Stjernberg \& Oskar Penje NORDREGIO REPORT 2019:1

Edition 2 
Population change dynamics in Nordic municipalities

- grid data as a tool for studying residential change at local level

Nordregio Report 2019:1

Edition 2: Correction to Table 9 have been made. In Edition 1 Shrinking ( $n$ ) and Growing $(n)$ headlines under Grid cell behavior were misplaced on wrong columns.

ISBN 978-91-87295-65-2

ISSN 1403-2503

DOI: doi.org/10.30689/R2019:1.1403-2503

(c) Nordregio 2019

Nordregio

P.O. Box 1658

SE-111 86 Stockholm, Sweden

nordregio@nordregio.org

www.nordregio.org

www.norden.org

Analyses and text: Mats Stjernberg \& Oskar Penje

Cover: Map by Oskar Penje

Repro and print: Allduplo

\section{Nordregio}

is a leading Nordic and European research centre for regional development and planning, established by the Nordic Council of Ministers in 1997. We conduct solution-oriented and applied research, addressing current issues from both a research perspective and the viewpoint of policymakers and practitioners. Operating at the international, national, regional and local levels, Nordregio's research covers a wide geographic scope, with an emphasis on the Nordic and Baltic Sea Regions, Europe and the Arctic.

\section{The Nordic co-operation}

Nordic co-operation is one of the world's most extensive forms of regional collaboration, involving Denmark, Finland, Iceland, Norway, Sweden, and the Faroe Islands, Greenland, and Åland. Nordic co-operation has firm traditions in politics, the economy, and culture. It plays an important role in European and international collaboration, and aims at creating a strong Nordic community in a strong Europe. Nordic co-operation seeks to safeguard Nordic and regional interests and principles in the global community. Common Nordic values help the region solidify its position as one of the world's most innovative and competitive.

\section{The Nordic Council of Ministers}

is a forum of co-operation between the Nordic governments. The Nordic Council of Ministers implements Nordic co-operation. The prime ministers have the overall responsibility. Its activities are co-ordinated by the Nordic ministers for co-operation, the Nordic Committee for co-operation and portfolio ministers. Founded in 1971.

\section{The Nordic Council}

is a forum for co-operation between the Nordic parliaments and governments. The Council consists of 87 parliamentarians from the Nordic countries. The Nordic Council takes policy initiative s and monitors Nordic co-operation. Founded in 1952. 


\section{Contents}

Preface

6

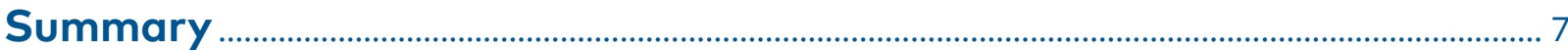

1. Introduction

2. The dynamics of population change at different territorial levels in the Nordic Region........................................................................................................................ 9

2.1 Population change at the municipal level................................................................................. 9

2.2 Population change and settlement patterns at the grid level .................................................... 11

2.3 The relationship between population development at the municipal and grid levels...........21

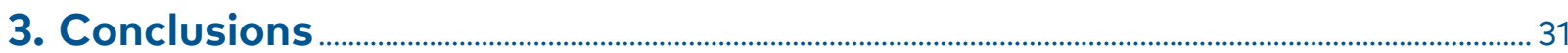

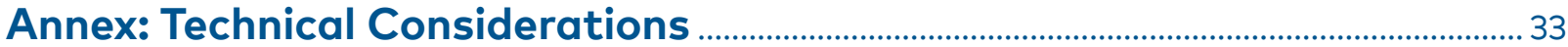

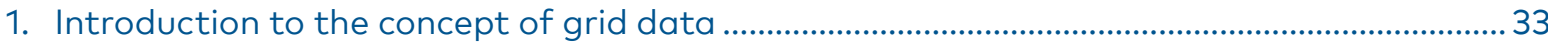

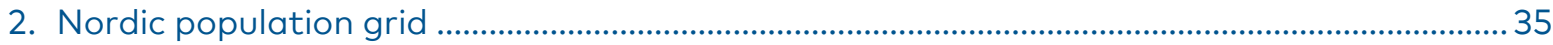

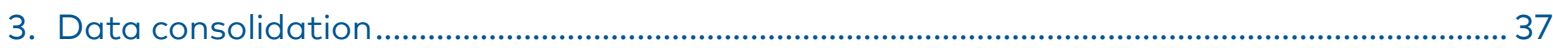

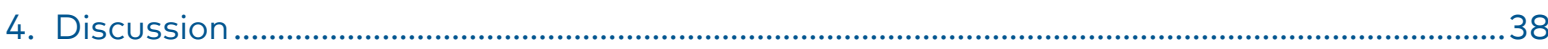

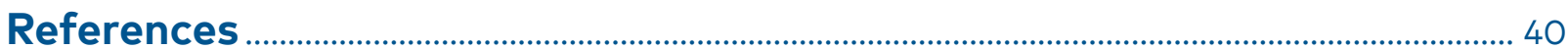

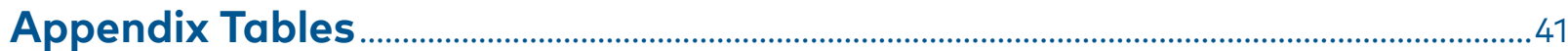




\section{Preface}

As part of the Nordic Co-operation Programme for Regional Development and Planning 20172020, three Nordic thematic groups have been established in the following areas:

1. Sustainable rural development

2. Innovative and resilient regions

3. Sustainable cities and urban development

The groups have been set up by the Nordic Committee of Senior Officials for Regional Policy (EK-R), under the Nordic Council of Ministers for Sustainable Growth, and the members are representatives of relevant ministries, national authorities, regional authorities and cross-border co-operation committees. One purpose of the thematic groups is to implement the co-operation programme by contributing to the exchange of knowledge and experience between regional policy stakeholders, by promoting Nordic perspectives and by highlighting the importance of regional policy issues for sustainable development and growth.

This report is the result of work done for the thematic group Sustainable Cities and Urban Development. The group focuses on: 1) social sustainability and gender equality; 2 ) spatial planning;
3) urban qualities in small and medium-sized cities, and the urban-rural relationship; and 4) the growth and development of Arctic cities. Within these broad themes the group decides what activities to conduct, and the researchers involved are responsible for the results.

In this report, grid-based statistics from different Nordic countries are used in an integrated way to study demographic changes at local level within regions, municipalities and cities; especially cities or towns that could be considered small and medium-sized. The objective is to form a deeper understanding of demographic developments occurring in the Nordics that may be less apparent at more general territorial levels, thus providing evidence to support spatial planning and decisionmaking.

The authors wish to thank the readers of the draft versions of the report and especially thank Johannes Lidmo for providing valuable support during the course of the work.

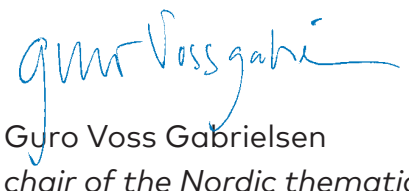

chair of the Nordic thematic group Sustainable

Cities and Urban Development 


\section{Summary}

In this report, grid-based statistics from different Nordic countries are used in an integrated way to study demographic changes at local level within regions, municipalities and cities; especially cities or towns that could be considered small and mediumsized. One of the main methodological questions guiding the study is how fine-grained grid-level statistics can be used as a compliment to more general statistics bound to administrative areas such as municipalities and regions. This report seeks to form a more nuanced understanding of the population developments occurring in the Nordics that may be less apparent, or not evident at all, at more general territorial levels. The intention of the study is to shed light on the following questions: What types of population dynamics occurred in the Nordic countries at the municipal and grid levels during 2008-2017? To what degree do changes at the local level correspond to more general population development at the municipal level? What types of changes can be seen within municipalities, especially in small and mediumsized cities?

The findings show that, the Nordic Region is undergoing highly unbalanced population development, and there are notable differences in demographic trends both between and within countries. For instance, population shrinkage is clearly more widespread in Finland, at both the municipal and grid levels, than in the other countries. In Sweden, growing municipalities clearly outnumber shrinking municipalities, but the sparsely populated northern parts of the country have typically decreasing populations. Distinctive for Norway is that population shrinkage is less common compared with the other countries, and, unlike in the northern parts of Finland and Sweden, there are several municipalities and towns in northern Norway where the population increased noticeably between 2008 and 2017. In Denmark, it is noteworthy that gridlevel statistics show that most of the Danish territory has decreased in population, even though most municipalities are growing.

Urbanization is a global megatrend, and the analyses confirm that this is occurring in Denmark, Finland, Norway and Sweden. In each country, population increase is concentrated in urban regions, especially the capital city regions of each country, followed by other major and medium-sized urban areas. By contrast, population shrinkage is generally less concentrated and is most evident in sparsely populated and rural areas. The analysis shows that population development at the grid level generally reflects the broader development seen at the municipal level, with the share of growing grid cells highest in the municipalities that had significant population growth, and the share of shrinking grid cells highest in municipalities witnessing population decrease. Nevertheless, growing municipalities are seldom entirely composed of growing areas, and most shrinking municipalities do not consist only of shrinking areas. Instead, the findings demonstrate that even though increases and decreases in population could be viewed as opposite lines of development, it is possible for population growth and shrinkage to occur within the same urban region or municipality.

All in all, the findings demonstrate that population data at the grid level are well-suited for identifying demographic change processes and trends occurring within regions and municipalities. While this study concentrates on changes in population size over time, it is evident that gridded statistics offer further potential for uncovering trends that are concealed at more general levels of analysis. To fully realise the potential of grid level data at the Nordic level, further harmonisation of data processing and availability is required. 


\section{Introduction}

The Nordic Region is currently undergoing a number of major demographic trends. The population is growing in all five Nordic countries, largely due to immigration, while also becoming increasingly concentrated in urban settlements. At the same, development in the Nordic Region is unbalanced: different regions and municipalities are experiencing noticeably different lines of development. While differences between regions and municipalities have been well documented (see e.g. Grunfelder et al. 2018), less is known about more local demographic changes, such as within regions and municipalities, and how these relate to their various types and sizes. Researchers and policymakers have focused mainly on larger cities and urban regions, and there is less empirical knowledge about the types of demographic change occurring in smaller Nordic cities and towns. Bell and Jayne (2009: 684) suggest that the dominant research focus on large urban areas may be because of the 'urban studies orthodoxy obsessed by the biggest scale of cities'. Perhaps more importantly, Servillo et al. (2017) argue that small and medium-sized cities have been largely neglected in urban research because of a lack of comparative data. Against this background, this study uses spatially detailed gridbased statistics from different Nordic countries in an integrated way to compare demographic changes within regions, municipalities and cities; especially cities or towns that could be considered small and medium-sized. This study has been guided by the following two methodological questions:

How can grid-level statistics from different Nordic countries be integrated in a way that allows for comparative analyses of phenomena and developments occurring within regions, municipalities and cities?
How can fine-grained grid-level statistics be used as a compliment to more general statistics bound to administrative areas such as municipalities and regions?

The dynamics of population change in the Nordic countries during 2008-2017 is the focus of this empirical study using statistical data at the municipal level, along with grid-level statistics at more local levels. These datasets are used in a complementary way. Detailed grid-level statistics expose phenomena and developments that cannot be seen at broader territorial levels. For instance, when large administrative areas such as regions or municipalities are the units of analysis, the complex dynamics of population changes at more local levels may be concealed. The objective is to describe, and form an understanding of, demographic changes within Nordic municipalities, especially in small and medium-sized cities. Specifically:

What types of population dynamics occurred in the Nordic countries at the municipal and grid levels during 2008-2017?

- To what degree do changes at the local level correspond to more general population development at the municipal level?

- What types of changes can be seen within municipalities, especially in small and medium-sized cities?

This report is presented in two parts. The Main Report focuses on the dynamics of population change in the Nordic countries. Technical considerations are then addressed, especially issues associated with the use of grid-level data from different Nordic countries and how harmonization between these different datasets was achieved. 


\section{The dynamics of population change at different territorial levels in the Nordic Region}

The population is currently growing in all five Nordic countries, predominantly in urban settlements. Within these general trends, there are significant differences between regions and municipalities creating considerable spatial complexity. This section of the report examines the spatial dynamics of population change at the municipal level, and more locally, at the grid level, in the Nordic countries during 2008-2017 (see Table 1). Part 2.1 details the population changes at the municipal level in Denmark, Finland, Iceland, Norway and Sweden. The interest here is to determine whether and to what degree the municipalities in these countries had increasing, stable or decreasing populations between 2008 and 2017. Part 2.2 examines population development at the grid level, where 1,000 × 1,000-m statistical grids are used for a more spatially detailed examination of population changes during the same period. This complements the more general municipal analysis and provides a more elaborated understanding of the dynamics of population change in various parts of the Nordic Region. The grid analysis includes the four Nordic countries for which comparable population data at the 1,000 × 1,000-m grid level are available for the years 2008 and $2017^{1}$, namely Denmark, Finland (including Åland), Norway and Sweden (see the Technical Considerations section for a more detailed presentation of the datasets). Grid-level statistics from these years are not currently available for Iceland and the autonomous territories of Greenland and the Faroe Islands. The connection between changes in population at the municipal and grid levels is addressed in part 2.3, specifically to what degree detailed local level changes correspond to the more general patterns observed at the municipal level. Zooming in on

1 The grid datasets used in the study reflect the situation on January 1 in both 2008 and 2017. specific municipalities illustrates the various forms of development occurring in small and mediumsized cities in Denmark, Finland, Norway and Sweden, while also identifying processes that may explain diverse intra-municipal outcomes.

\begin{tabular}{|c|c|c|}
\hline & \multicolumn{2}{|c|}{ Population change 2008-2017 } \\
\hline & Municipal level & Grid level \\
\hline Denmark & $x$ & $x$ \\
\hline Finland & $x$ & $x$ \\
\hline Iceland & $x$ & \\
\hline Norway & $x$ & $x$ \\
\hline Sweden & $x$ & $x$ \\
\hline
\end{tabular}

\subsection{Population change at the municipal level}

When examining population change at the municipal level, considerable variation can be observed within wider regions and from one country to another. Each municipality in Denmark, Finland, Iceland, Norway and Sweden has been classified, using five categories, according to their relative population change between 2008 and 2017:

1) Significantly growing (population increase of $5 \%$ or more)

2) Moderately growing (population increase between $2 \%$ and $5 \%$ )

3) Stable (population change between - $2 \%$ and $2 \%$ )

4) Moderately shrinking (population decrease between $2 \%$ and $5 \%$ )

5) Significantly shrinking (population decrease of $5 \%$ or more) 
According to this classification, the majority of municipalities in Denmark, Norway and Sweden have been either "moderately" or "significantly growing," with population increases of at least $2 \%$ (see Tables 2 and 3). Norway, in particular, has many municipalities (46.0\%) that are classified as "significantly growing." Also, in Denmark, Iceland and Norway, "significantly growing" is the most common category. Iceland, however, differs from the other Nordic countries, in that it has a high share of both "significantly growing" and "significantly shrinking" municipalities, underlining the fact that Icelandic municipalities have highly differing lines of development. By contrast, Finland has a noticeably greater share of municipalities that have decreased in population size compared with the other countries. Just over half of all Finnish municipalities are "significantly shrinking," whereas only around one-tenth of the municipalities in Denmark, Norway and Sweden have experienced similar population decreases.

The patterns of population change based on this classification are illustrated in Figure 1. The map clearly reveals the unbalanced nature of population development in the Nordic region, with noticeable differences both between and within countries. It is apparent that population shrinkage is more widespread in Finland than in the other countries. In Sweden, growing municipalities clearly outnumber shrinking municipalities, but a north-south divide is apparent. The municipalities in southern Sweden have almost all been growing rapidly, whereas those in the northern parts of the country have predominantly decreased in population. The map shows that while shrinking municipalities are relatively few in number in Sweden, these occupy significant territory in the northern counties of Jämtland, Västerbotten and Norrbotten due to their large geographical size. In this area, the majority of municipalities have a population density of less than two persons per square kilometre (Statistics Sweden 2018). In Norway, a distinctive division within the country is less evident, with relatively few municipalities showing a population decline. Unlike the northern parts of Finland and Sweden, where most municipalities are shrinking, there are several northern municipalities in Norway that experienced a substantial population increase between 2008 and 2017. In Denmark, most municipalities have increased in population, but the map shows that certain parts of the country, such as Lolland and the western areas, have population shrinkage. Highly unbalanced development is evident in Iceland, with relatively high numbers of both "significantly shrinking" and "significantly growing" municipalities.

These patterns of population change should be considered relative to other demographic changes and structural developments that can be observed in the population dynamics of Nordic regions and municipalities (see Grunfelder et al. 2018). For example, the municipalities that stand out as shrinking are largely those that are witnessing a profound ageing of the population. They have a comparatively high old-age dependency ratio, i.e. a high number of elderly inhabitants (aged 65 years and over) com-

\section{Table 2. The number of different municipalities clasified according to their relative population change (2008-2017).}

\begin{tabular}{|l|c|c|c|c|c|c|}
\hline & Denmark & Finland & Iceland & Norway & Sweden & Total \\
\hline $\begin{array}{l}\text { Significantly growing (population } \\
\text { increase of 5\% or more) }\end{array}$ & 32 & 56 & 23 & 194 & 112 & 394 \\
\hline $\begin{array}{l}\text { Moderately growing (population } \\
\text { increase between 2\% and 5\%) }\end{array}$ & 22 & 25 & 5 & 60 & 60 & 167 \\
\hline $\begin{array}{l}\text { Stable (population change between } \\
-2 \% \text { and 2\%) }\end{array}$ & 25 & 40 & 14 & 79 & 67 & 211 \\
\hline $\begin{array}{l}\text { Moderately shrinking (population } \\
\text { decrease between 2\% and 5\%) }\end{array}$ & 9 & 34 & 12 & 51 & 28 & 122 \\
\hline $\begin{array}{l}\text { Significantly shrinking (population } \\
\text { decrease of 5\% or more) }\end{array}$ & 11 & 156 & 20 & 38 & 23 & 228 \\
\hline Total & 99 & 311 & 74 & 422 & 290 & 1122 \\
\hline
\end{tabular}




\begin{tabular}{|c|c|c|c|c|c|c|}
\hline & Denmark & Finland & Iceland & Norway & Sweden & Total \\
\hline $\begin{array}{l}\text { Significantly growing (population } \\
\text { increase of } 5 \% \text { or more) }\end{array}$ & $32.3 \%$ & $18.0 \%$ & $31.1 \%$ & $46.0 \%$ & $38.6 \%$ & $35.1 \%$ \\
\hline $\begin{array}{l}\text { Moderately growing (population } \\
\text { increase between } 2 \% \text { and } 5 \% \text { ) }\end{array}$ & $22.2 \%$ & $8.0 \%$ & $6.7 \%$ & $14.2 \%$ & $20.7 \%$ & $14.9 \%$ \\
\hline $\begin{array}{l}\text { Stable (population change between } \\
-2 \% \text { and } 2 \% \text { ) }\end{array}$ & $25.3 \%$ & $12.9 \%$ & $18.9 \%$ & $18.7 \%$ & $23.1 \%$ & $18.8 \%$ \\
\hline $\begin{array}{l}\text { Moderately shrinking (population } \\
\text { decrease between } 2 \% \text { and } 5 \% \text { ) }\end{array}$ & $9.1 \%$ & $10.9 \%$ & $16.2 \%$ & $12.1 \%$ & $9.7 \%$ & $10.9 \%$ \\
\hline $\begin{array}{l}\text { Significantly shrinking (population } \\
\text { decrease of } 5 \% \text { or more) }\end{array}$ & $11.1 \%$ & $50.2 \%$ & $27.0 \%$ & $9.0 \%$ & $7.9 \%$ & $20.3 \%$ \\
\hline
\end{tabular}

pared with the number of people who are of working age (aged 15-64 years) (Sánchez Gassen 2018). It is also pertinent that international migration is the most important driver of population growth in the Nordic countries, accounting for $70 \%$ of the population increase during the 2000s (Heleniak 2018). At the municipal level, many large cities that have substantially increased in population also have comparatively high shares of inhabitants with foreign backgrounds. By contrast, many shrinking municipalities in Finland and Iceland have low international net migration rates. Shrinkage has been described by Bontje and Musterd (2012: 154) as a complex interplay of different factors, where economic stagnation and population decline are closely intertwined. This appears to be the case in many parts of the Nordic Region, where regions and municipalities that are undergoing shrinkage are characterized not only by decreasing and ageing populations, but also generally by comparatively higher unemployment rates (Karlsdóttir et al. 2018) and often by unfavourable employment opportunities. For instance, in the Finnish context, Kotilainen et al. (2015) note that a typical feature of many cities and regions that are witnessing population decline is that they have been economically dependent on the processing of natural resources, especially timber and minerals. As a result of structural changes in the global division of labour, employment opportunities have frequently declined in these regions. This has led to regional outmigration, especially among younger age groups, resulting in a proportionately higher share of elderly inhabit- ants. Based on Nordregio's Regional Potential Index, which ranks Nordic regions according to their demographic potential, labour market potential and economic potential, most regions that include at least one bigger city rank relatively higher, whereas many sparsely populated regions rank lower (Grunfelder 2018).

These population changes across the Nordic region highlight the unbalanced nature of population dynamics both between and within countries. Nevertheless, when considering only relatively large administrative areas, such as regions or municipalities, the greater complexity of local population dynamics may be concealed. The next section looks at population changes in more detail.

\subsection{Population change and settlement patterns at the grid level}

Grid-level statistics are used here to examine population change and settlement patterns in the Nordic countries. The intention is to establish a more fine-grained understanding of the dynamics of population change and to uncover settlement and development patterns that are less apparent at the municipal level. Population data at the 1,000 $\times 1,000-\mathrm{m}$ grid level are currently available for the years 2008 and 2017 from Denmark, Finland (including Åland), Norway and Sweden. While Iceland could not be included in the analysis of population change at the grid level, it is included in Figure 2, which shows grid-level population densities using data from another year (see Technical Considerations for details of data availability). 


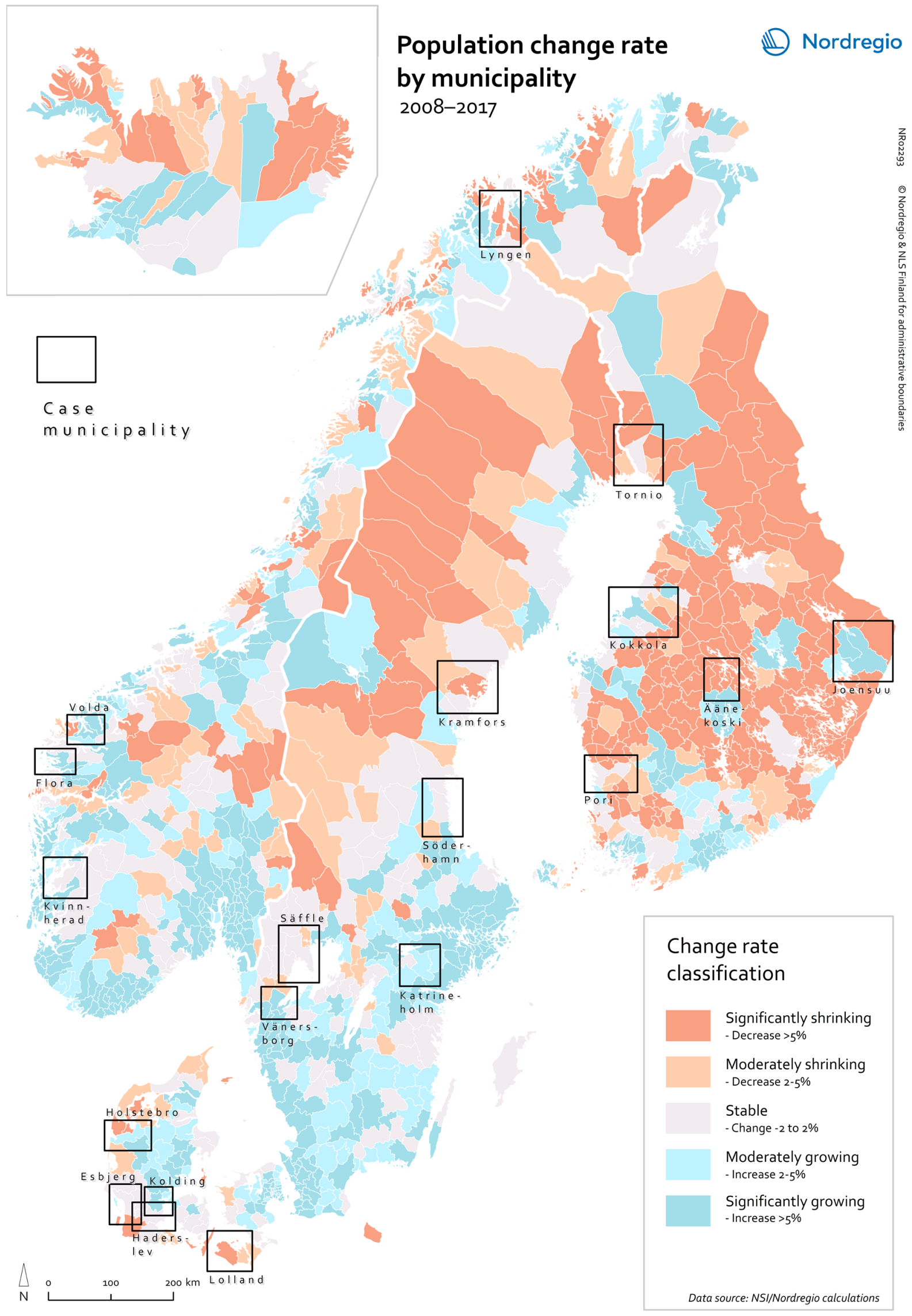

Figure 1. Relative change in population size at the municipal level in the Nordic region, 2008-2017. Map by Oskar Penje. 


\section{NORDIC GRID-LEVEL STATISTICS IN BRIEF}

Official statistics are traditionally based on a hierarchical system of administrative areas, ranging from local administrative units to municipalities and regions, and extending up to the national level. Gridlevel statistics, by contrast, are produced by first establishing point locations for the population, usually according to each person's residential address. With the use of geographic information systems (GIS), these points are then overlaid with a grid of a chosen cell size, and the data from the contained location points are aggregated to estimate an overall data value for each grid cell. The content of an existing grid dataset may also be aggregated to a larger grid size. For instance, in Figures 2 and 3 of this report, the populations in the original 1,000 $\times 1,000$ - $m$ grid have been aggregated to a larger $5,000 \times 5,000 \mathrm{~m}$ grid to facilitate an easier interpretation across the Nordic Region. For a more detailed description of this aggregation process, see Technical Considerations.

\section{Settlement patterns in the Nordics}

The settlements of the Nordic countries are rather unevenly distributed (Figure 2). The Nordic population is largely concentrated in coastal areas. These contain the major urban regions in all five countries. Current settlement patterns seem to reflect historical patterns that have been determined by the physical geography, including the availability of arable agricultural land and access to waterways (see Sporrong 2008; Smas 2018). Highly concentrated settlement is most evident in Iceland, where the population is primarily in the south-western corner of the country around the Reykjavík capital region, while the inner parts of the country are largely uninhabited. In Norway, the most noticeable population concentrations are found around the Oslo capital region and along the south-western coast. In Sweden, the Stockholm and Gothenburg regions stand out as the most densely populated areas in the country, and these two regions are connected by an east-west corridor of comparatively high population density. The south-western coast of Sweden, extending from near Oslo to greater Copenhagen, also stands out as a densely populated settlement corridor. The Finnish population is largely concentrated in the south, mostly in the triangle connecting the urban regions of Helsinki, Tampere and Turku. There are also some clear differences between countries: for example, there are comparatively more areas that are entirely uninhabited in Norway and Sweden than in Finland. By contrast, there are noticeably more very sparsely populated areas in Finland than in Norway and Sweden. This observation reflects the physical geography of the countries: many parts of Norway and north-western Sweden have vast mountainous areas that are largely uninhabited. The map also shows a substantially higher population density in Denmark than in the other Nordic countries, but, as in the other countries, the population is largely concentrated around the major urban centres, namely Copenhagen, Aarhus and Aalborg.

Tables 3 and 4 further underline the substantial difference in settlement patterns between Denmark and the other Nordic countries. For instance, the 2017 share of grid cells $(1,000 \times 1,000$ $\mathrm{m}$ ) that were inhabited by at least one person is substantially higher in Denmark (83.3\%) than in Finland (29.8\%), Norway (15.9\%) or Sweden (25.5\%). Similarly, the share of grid cells that are very sparsely populated or entirely uninhabited was noticeably lower in Denmark than in the other three countries. These observations are consistent with Denmark's considerably higher population density (136 persons per $\mathrm{km}^{2}$ ) relative to Finland (18 persons per $\mathrm{km}^{2}$ ), Norway (17 persons per $\mathrm{km}^{2}$ ) or Sweden (24 persons per $\mathrm{km}^{2}$ ) (Eurostat 2018). However, what is more unexpected are the rather clear distinctions that can be made between Finland, Norway and Sweden. Even though all three countries have relatively similar population densities on the national scale, the share of "highly sparse" grid cells with only one or two residents is substantially higher in Finland (21.3\%) than in Norway $(12.3 \%)$ or Sweden (10.3\%). At the same time, the share of entirely uninhabited grid cells is lower in Finland (68.3\%) than in Norway (83.2\%) or Sweden (72.8\%). These observations, also evident in Figure 2 , correspond to the previously discussed differences in settlement patterns. While physical geography is undoubtedly an important determinant of both historical and contemporary settlement patterns, differences in the history of urbanization are also contributing factors. For instance, outmigra- 
tion from the countryside started in Sweden in the middle of the nineteenth century, and by 1935 , the share of the population living in urban settlements was similar to that living in rural areas (Smeds \& Mattila 1941). By contrast, urbanization came later in Finland, and as a result, the country remained a predominantly agrarian society until the 1950s. In 1950, nearly half of the population worked in agriculture and forestry and two-thirds lived in rural areas (Statistics Finland 2007). The proportionately greater share of highly sparse areas in Finland compared with Sweden may reflect these different phases of urbanization. In Sweden, the sparse territories have depopulated over a longer period of time compared with Finland. While urbanization started later in Finland, it now seems to be undergoing the most rapid urbanization of the four countries, as is discussed in the following section.

\section{Population change at the grid level 2008-2017}

Just as the comparison of population changes at the municipal level (in part 2.1) showed noticeable differences between Denmark, Finland, Norway and Sweden, an analysis of population changes at the grid level also highlights certain differences among countries and reveals certain facets of change that are not evident at the municipal level. This is apparent when comparing the proportion of growing and shrinking grid cell populations in each of the four countries (Tables 5 and 6). A growing cell has at least one more person in 2017 than in 2008, whereas a shrinking cell has at least one less person. Only in Sweden are there more growing than shrinking grid cells. In Norway, the number of growing and shrinking grid cells is approximately the same, and in Denmark and

Table 4. The number of grid cells $(1,000 \times 1,000 \mathrm{~m})$ by category, illustrating differences in settlement patterns between Denmark, Finland, Norway and Sweden.

\begin{tabular}{|l|r|r|r|r|r|r|}
\hline & All grid cells & $\begin{array}{r}\text { Inhabited } \\
\text { grid cells } \\
\mathbf{( 2 0 0 8 )}\end{array}$ & $\begin{array}{r}\text { Inhabited } \\
\text { grid cells } \\
\mathbf{( 2 0 1 7 )}\end{array}$ & $\begin{array}{r}\text { Inhabited } \\
\text { grid cells } \\
\text { (at least } \\
\text { one year) }\end{array}$ & $\begin{array}{r}\text { Highly sparse } \\
\text { grid cells }\end{array}$ & $\begin{array}{r}\text { Uninhabited } \\
\text { grid cells } \\
\text { (both years) }\end{array}$ \\
\hline Denmark & 46,732 & 39,016 & 38,908 & 39,404 & 1,799 & 7,328 \\
\hline Finland & 334,955 & 102,024 & 99,913 & 106,275 & 22,589 & 228,680 \\
\hline Norway & 345,540 & 55,509 & 55,048 & 57,965 & 7,148 & 287,575 \\
\hline Sweden & 445,226 & 114,823 & 113,363 & 120,936 & 12,294 & 324,290 \\
\hline
\end{tabular}

Table 5 . The share of grid cells $(1,000 \times 1,000 \mathrm{~m})$ by category, illustrating differences in settlement patterns between Denmark, Finland, Norway and Sweden.

\begin{tabular}{|l|r|r|r|r|r|}
\hline & $\begin{array}{r}\text { Inhabited grid } \\
\text { cells (2008) }\end{array}$ & $\begin{array}{r}\text { Inhabited grid } \\
\text { cells (2017) }\end{array}$ & $\begin{array}{r}\text { Inhabited grid } \\
\text { cells (at least } \\
\text { one year) }\end{array}$ & $\begin{array}{r}\text { Highly sparse } \\
\text { grid cells }\end{array}$ & $\begin{array}{r}\text { Uninhabited } \\
\text { grid cells (both } \\
\text { 2008 and 2017) }\end{array}$ \\
\hline Denmark & $83.5 \%$ & $83.3 \%$ & $84.3 \%$ & $4.6 \%$ & $15.7 \%$ \\
\hline Finland & $30.5 \%$ & $29.8 \%$ & $31.7 \%$ & $21.3 \%$ & $68.3 \%$ \\
\hline Norway & $16.1 \%$ & $15.9 \%$ & $16.8 \%$ & $12.3 \%$ & $83.2 \%$ \\
\hline Sweden & $25.8 \%$ & $25.5 \%$ & $27.2 \%$ & $10.3 \%$ & $72.8 \%$ \\
\hline
\end{tabular}

"All grid cells" include all grid cells that intersect land areas in Denmark, Finland, Norway and Sweden.

"Inhabited grid cells" include all grid cells with at least one inhabitant in 2008 or 2017.

"Highly sparse grid cells" include all grid cells with one or two inhabitants in 2008 and 2017.

"Uninhabited grid cells" include all grid cells with no inhabitants in 2008 and 2017. 


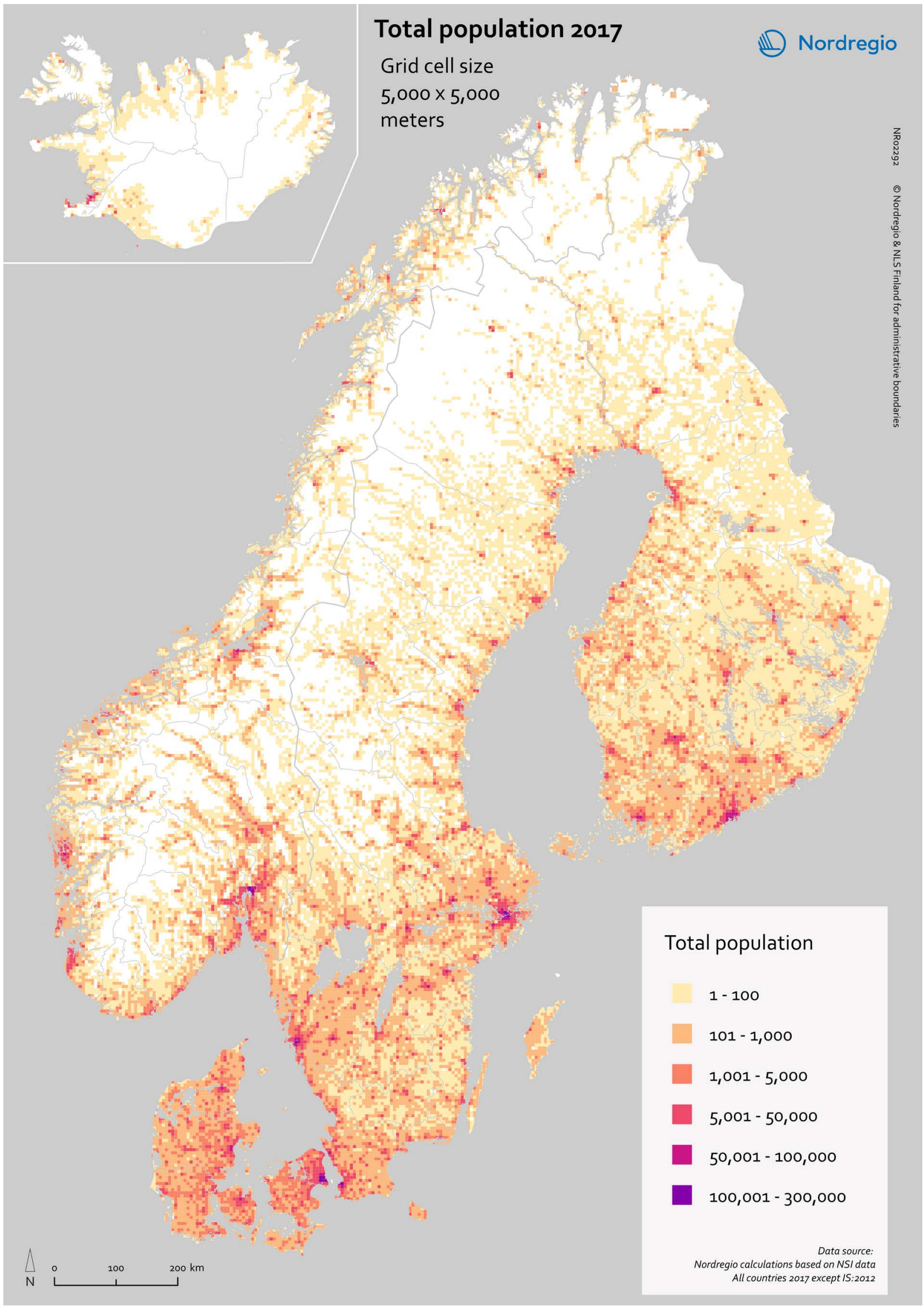

Figure 2. Total population at the grid level (5,000 × 5,000 m) in Denmark, Iceland, Finland, Norway and Sweden. Map by Oskar Penje. 
Finland, shrinking grid cells clearly outnumber those with a population increase. It is noteworthy that while the previously discussed municipal-level statistics show that most Danish municipalities increased their population during the period of analysis (Table 2, Figure 1), according to the grid-level statistics, most of the Danish territory decreased in population size over the same period. While the difference between Denmark and Finland is clear at the municipal level, in the sense that most Danish municipalities are growing while most Finnish municipalities are shrinking, at the grid level, both Denmark and Finland are characterized by more areas where the population is shrinking than growing. Although only around one-fifth of Danish municipalities declined in population by $2 \%$ or more, all the municipalities have significant areas in which the population is decreasing.

A trend that can be seen in all four countries is that the number of inhabited grids has diminished (Tables 4 and 5), indicating that the population in all countries is becoming increasingly concentrated. This change is especially significant in Finland, where the number of inhabited grid cells decreased by approximately $2 \%$ (from 102,024 to 99,913) between 2008 and 2017. Another indication of an increasing concentration of population is that there are more "recently abandoned" than "recently inhabited" grid cells in all four countries (Tables 6 and 7). "Recently

\begin{tabular}{|c|c|c|c|c|c|c|}
\hline & $\begin{array}{r}\text { Inhabited grid } \\
\text { cells (at least } \\
\text { one year) }\end{array}$ & $\begin{array}{l}\text { Growing } \\
\text { grid cells }\end{array}$ & $\begin{array}{r}\text { Shrinking } \\
\text { grid cells }\end{array}$ & $\begin{array}{r}\text { Entirely } \\
\text { unchanged } \\
\text { grid cells }\end{array}$ & $\begin{array}{r}\text { Recently } \\
\text { abandoned } \\
\text { grid cells }\end{array}$ & $\begin{array}{r}\text { Recently } \\
\text { inhabited } \\
\text { grid cells }\end{array}$ \\
\hline Denmark & 39,404 & 14,000 & 20,333 & 3,272 & 496 & 388 \\
\hline Finland & 106,275 & 26,781 & 46,793 & 10,112 & 6,362 & 4,251 \\
\hline Norway & 57,965 & 23,123 & 23,329 & 4,365 & 2,917 & 2,456 \\
\hline Sweden & 119,861 & 52,093 & 46,867 & 8,607 & 7,573 & 6,113 \\
\hline
\end{tabular}

Table 7. The share of different types of grid cells $(1,000 \times 1,000 \mathrm{~m})$ illustrating differences in population change between Denmark, Finland, Norway and Sweden.

\begin{tabular}{|l|r|r|r|r|r|}
\hline & $\begin{array}{r}\text { Growing } \\
\text { grid cells }\end{array}$ & $\begin{array}{r}\text { Shrinking } \\
\text { grid cells }\end{array}$ & $\begin{array}{r}\text { Entirely } \\
\text { unchanged } \\
\text { grid cells }\end{array}$ & $\begin{array}{r}\text { Recently } \\
\text { abandoned } \\
\text { grid cells }\end{array}$ & $\begin{array}{r}\text { Recently } \\
\text { inhabited } \\
\text { grid cells }\end{array}$ \\
\hline Denmark & $35.5 \%$ & $51.6 \%$ & $8.3 \%$ & $1.3 \%$ & $1.0 \%$ \\
\hline Finland & $25.2 \%$ & $44.0 \%$ & $9.5 \%$ & $6.2 \%$ & $4.3 \%$ \\
\hline Norway & $39.9 \%$ & $40.2 \%$ & $7.5 \%$ & $5.3 \%$ & $4.5 \%$ \\
\hline Sweden & $43.5 \%$ & $39.1 \%$ & $7.2 \%$ & $6.6 \%$ & $5.4 \%$ \\
\hline
\end{tabular}

"Inhabited grid cells" include all grid cells with at least one inhabitant in 2008 or 2017.

"Growing grid cells" include all grid cells (with at least three inhabitants) where the population increased from 2008 to 2017.

"Shrinking grid cells" include all grid cells (with at least three inhabitants) where the population decreased from 2008 to 2017.

"Entirely unchanged grid cells" include all grid cells with the same population in 2008 and 2017.

"Recently abandoned grid cells" include all grid cells that had at least one inhabitant in 2008, but were completely uninhabited in 2017.

"Recently inhabited grid cells" include all grid cells that did not have a single inhabitant in 2008, but had at least one inhabitant in 2017. 
abandoned" grid cells are areas that had at least one inhabitant in 2008, but not a single inhabitant in 2017, whereas "recently inhabited" grid cells were completely uninhabited in 2008 , but had at least one inhabitant in 2017. While all four countries have a noticeably higher share of abandoned than newly inhabited areas, this difference is the most evident in Finland, where there are 6,362 recently abandoned compared with 4,251 recently inhabited grid cells. Overall, these developments indicate that Denmark, Finland, Norway and Sweden are undergoing urbanization, and while the population in each country increased during the study period, at the same time, the inhabited land area has decreased in all four countries. This line of development is most noticeable in Finland, suggesting that Finland is currently undergoing the most profound urbanization among the four countries.

The patterns of population change that can be seen at the 5,000 $\times 5,000$-m grid level in Denmark, Finland, Norway and Sweden during 20082017 are shown in Figure 3. The original data at the $1,000 \times 1,000-m$ grid level have been aggregated to a larger grid for visualization purposes, as 1,000 $\times 1,000$-m grid cells are not easily identifiable in maps covering the whole Nordic Region (see Technical Considerations). In Figure 3, the major urban regions stand out as the most significant areas of population increase in all four countries. Population increase is most evident in the capital city regions of each country, but is also apparent in other major and medium-sized urban regions. In Denmark, the Copenhagen area represents the largest concentration of population increase, but Aarhus, and to a lesser extent Odense and Aalborg, stand out as growing urban regions. In Finland, the urban region of Helsinki is the most visible growing region, with Tampere, Oulu, Turku, Jyväskylä and Joensuu also representing urban regions where noticeable population increase has occurred. In Norway, the most recognizable concentration of population increase is around Oslo, while other noticeable growth regions are along the coast around Bergen, Stavanger, Kristiansand and Trondheim. In Sweden, the Stockholm region represents the most visible concentration of population increase, followed by the Gothenburg region. Other clear concentrations of population growth in Sweden include the Malmö region, and, to a lesser extent, certain medium-sized city regions such as Jönköping, Linköping, Umeå, Växjö and Örebro.
In terms of population decrease, Figure 3 shows that in Denmark, the urban regions of Odense, Aarhus and Aalborg, in particular, are largely surrounded by areas of population shrinkage. In Denmark, areas of declining population are found especially in the northern and southern parts of Jylland, in Lolland and in Bornholm. Similarly, in Finland, the main urban regions characterized by population growth are surrounded by grid cells where the population is decreasing. Even though shrinking cells can be found throughout the country, certain regions, such as Kymenlaakso in south-eastern Finland and Kainuu in the north-east, are dominated by shrinking cells, with these regions containing few growing cells. Both Denmark and Finland have more shrinking than growing grid cells. However, the areas of population decline in Denmark are more visible, having less gaps between them as a result of the considerably higher overall population density. Population shrinkage in Finland, on the other hand, is dispersed over vaster and more sparsely populated areas. Similarly, Tables 6 and 7 show that the number of shrinking grid cells is proportionately much greater in Finland than in Sweden or Norway. Figure 3 clearly illustrates this significant difference; shrinking areas are clearly more common and dispersed over vast territories in Finland. In Norway, there are comparatively few shrinking grid cells, and the map shows that these are relatively scattered around the country. Unlike in Denmark and Finland, where there are vast and continuous areas of significant population shrinkage, the scattered shrinking areas in Norway mainly show moderate population decrease. Sweden is notable in having fewer shrinking than growing areas, especially in the south. There are noticeably more areas of population decrease in the central and northern parts of Sweden than in the south, but even in these areas, the shrinkage is clearly less apparent compared with Denmark or Finland. A noticeable difference when comparing the northern parts of Finland, Norway and Sweden is that there are several concentrations of population increase in arctic Norway, including the medium-sized cities of Bodø and Troms $\varnothing$ and their surroundings. Although there are some growing areas in northern Finland and Sweden, these are substantially fewer, and in northern Finland, especially, population shrinkage is clearly more common than is population growth.

Overall, the spatial patterns of population increase and decrease in Denmark, Finland, Norway and Sweden clearly show that population growth 


\section{Total population change 2008-2017 in Denmark, Finland, Norway and Sweden}

\section{Grid cell size}

$5,000 \times 5,000$ meters

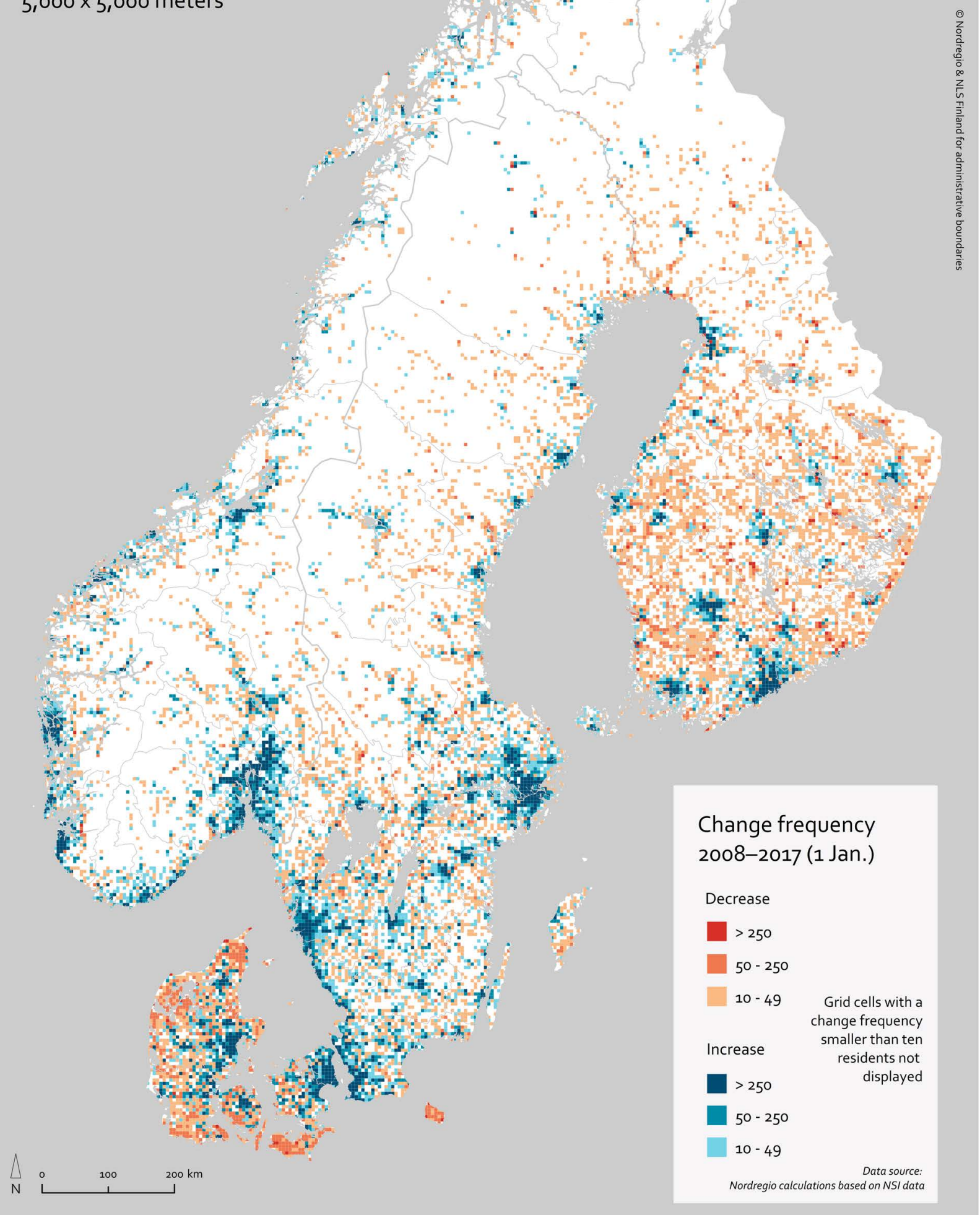

Figure 3. Absolute population change at the grid level $(5,000 \times 5,000 \mathrm{~m})$ in Denmark, Finland, Norway and Sweden between 2008 and 2017. Map by Oskar Penje. 
has been concentrated in large and medium-sized cities and their surrounding regions, whereas population decrease has typically been dispersed over larger areas. The clustered nature of population increase is indicated by the substantially greater number of grid cells of substantial population growth (an increase of more than 250 people per 5,000 × 5,000-m grid cell, displayed in dark blue), with fewer cells where the population has decreased to the same degree (displayed in dark red). This could be expected, as the most substantial population growth has occurred in urban regions, where population density is higher. Population shrinkage, on the other hand, is generally in sparsely populated rural areas. Comparing Figure 2 , which shows population density at the grid level, with Figure 3, which portrays the spatial patterns of population change, it is clear that population decrease has occurred mainly in sparsely populated areas.

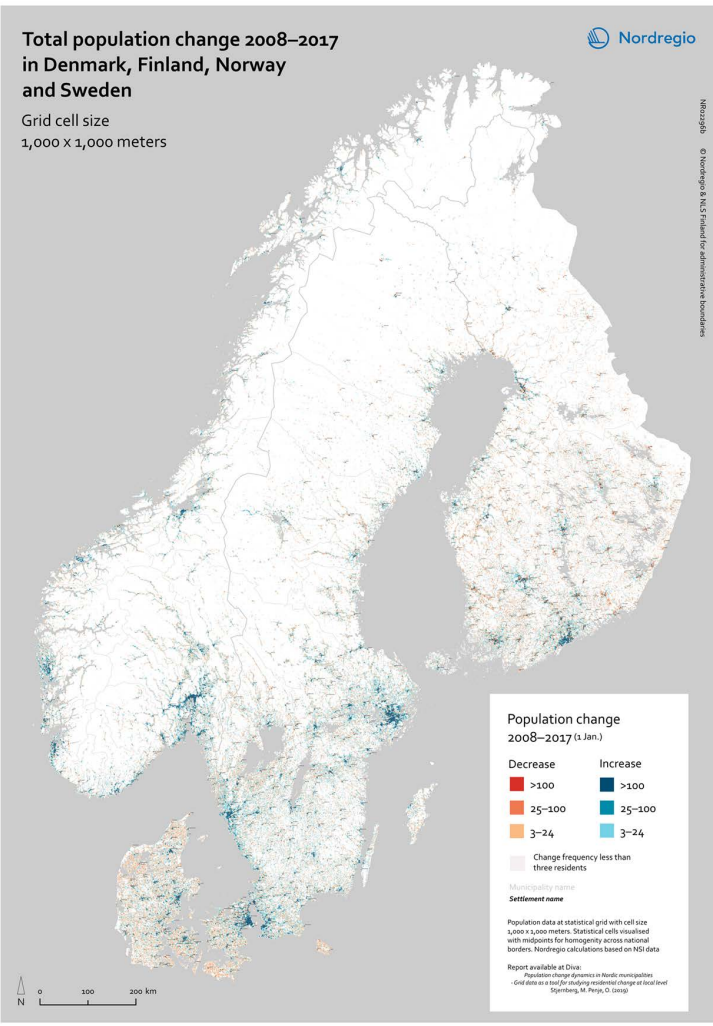

Maps by Oskar Penje.
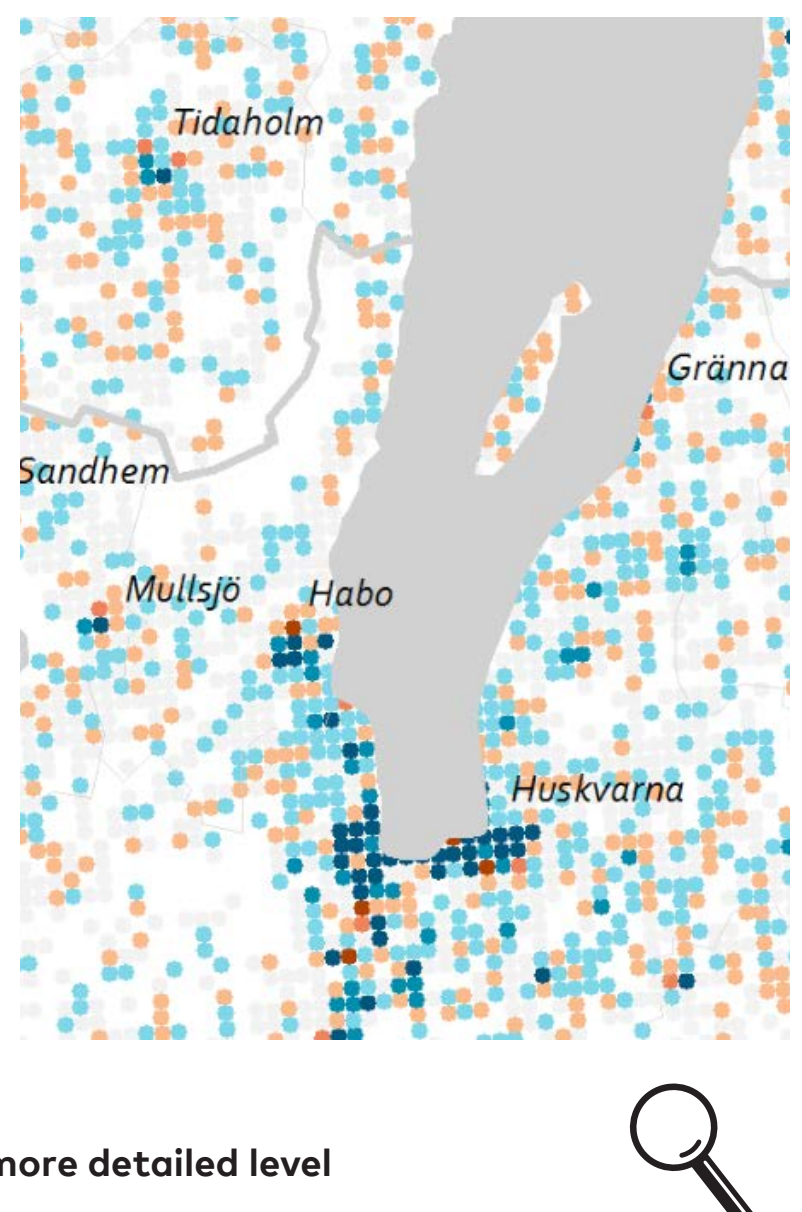

format for an easier visualization and interpretation. As illustrated above, this map includes place names, which allows an examination of levels of change in cities and towns of different sizes.

To access this map, please use the following link: http://urn.kb.se/resolve?urn=urn:nbn:se:n orden:org:diva-5425 uses the original grid data converted into point 


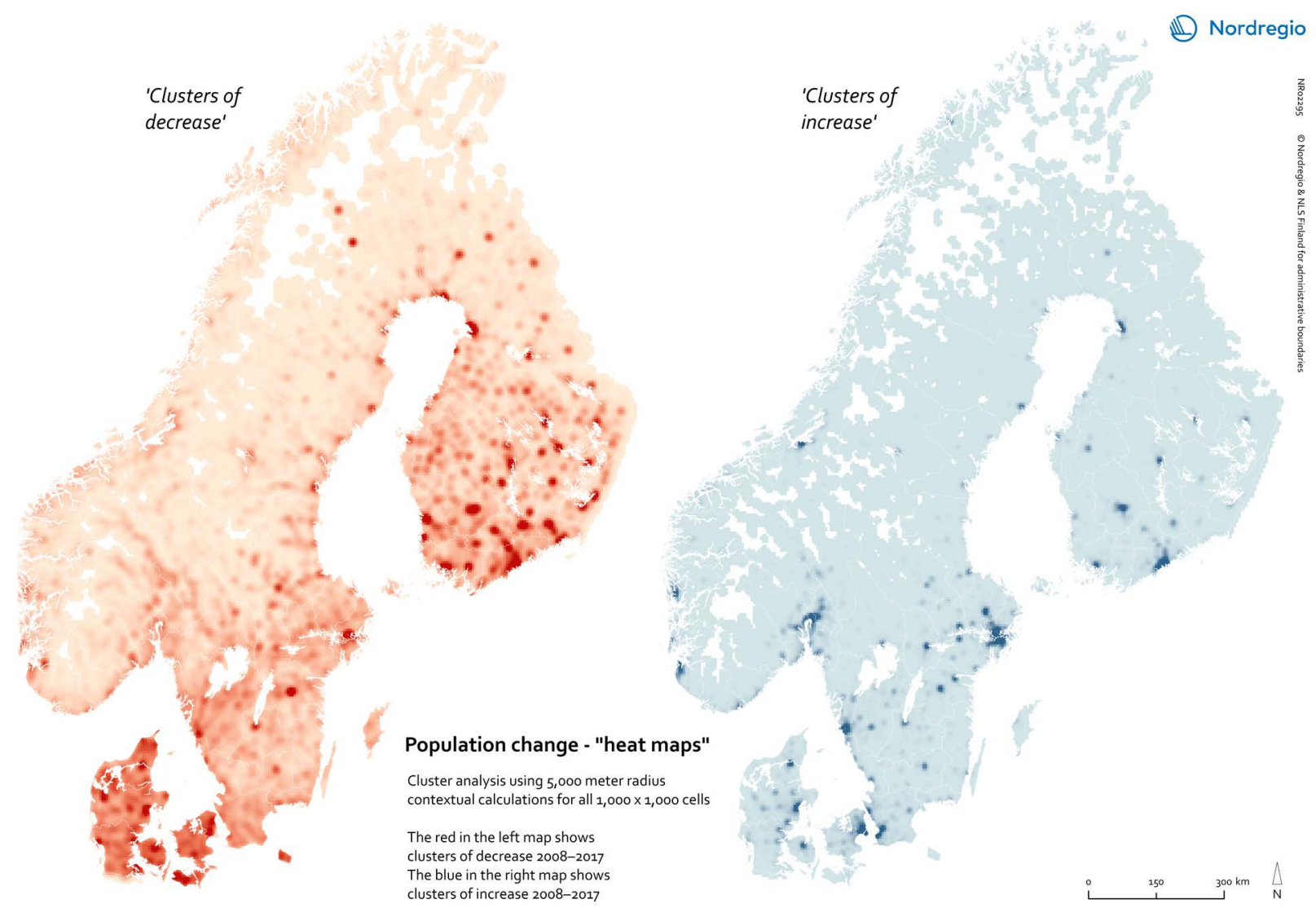

Figure 4. Clustered frequencies of population decrease (on the left side) and increase (on the right side) in Denmark, Finland, Norway and Sweden between 2008 and 2017. Maps by Oskar Penje.

A different outlook on the dynamics of population change in Denmark, Finland, Norway and Sweden is provided by Figure 4, which shows clusters of population increase (on the right side) and decrease (on the left side) in two separate "heat maps". These maps are the result of contextual calculations of the population change based on a 5,000-m radius surrounding each grid cell. Darker shades indicate a higher frequency of cluster cells having large population changes: decreases in red on the left and increases in blue on the right

The population growth clusters in Figure 4 are highly comparable to the population change at the 5,000 $\times 5,000$-m grid level seen in Figure 3 . In each country, major urban regions stand out as concentrations of population increase (indicated by darker shades of blue) along with certain other relatively large and dense urban regions. In Denmark, the regions around Copenhagen, Aarhus, Aalborg and Odense are the only clearly recognizable clusters of growth. In Norway, the regions of Oslo, Bergen, Stavanger and Trondheim are the most clearly visible. In Finland, the regions around
Helsinki, Tampere, Oulu and, to a lesser extent, Turku and Jyväskylä, stand out as clusters of population increase; a few other Finnish regions suggest less pronounce growth. In Sweden, the Stockholm, Gothenburg and Malmö regions can be identified as the main clusters of growth, but lesser growth can also be detected in the regions around Uppsala, Örebro, Västerås, Norrköping, Linköping and Umeå.

By contrast, the left side of the map shows clusters of population decrease in different shades of red. This map provides an inverted picture of the dynamics of population change compared with the growth map; the change frequencies in both maps have been calculated according to the same criteria. Of the four countries, Denmark and Finland stand out as having the most clearly recognizable concentrations of population decrease. In both Denmark and Finland, the clusters of population decrease are clearly more recognizable and greater in number compared with the clusters of population increase. The concentrations of population shrinkage are visually more apparent in Denmark than in Finland, which reflects Denmark's substantially 
higher population density. As places with high population density are more likely to be visible in these maps, it is appropriate that Denmark is the country that stands out the most in this regard. A noticeably different picture can be detected in Sweden, and particularly in Norway, where there are significantly fewer and less clearly recognizable concentrations of population decrease than in Denmark and Finland.

It is clear in Figure 4, but less evident in Figure 3 , that increases and decreases in population size are not mutually exclusive; indeed, these may occur in the same regions and cities. For instance, in Denmark, the four main clusters of population growth (Copenhagen, Aarhus, Aalborg and Odense) also stand out as clusters of shrinkage. In these cases, certain suburban areas outside of the main city centres decreased in population between 2008 and 2017. Even though increases and decreases in population could be viewed as opposite lines of development, it is possible for population growth and shrinkage to occur within the same urban region, even when the population of the urban region as a whole is growing. Similarly, in Finland, all the major urban regions that stand out as concentrations of population increase (Helsinki, Tampere, Oulu, Turku and Jyväskylä) are evidently also concentrations of population decrease. Similarly, in Sweden, several of the main clusters of population decrease are found in similar places to the most apparent clusters of population increase: the regions of Stockholm, Gothenburg and Linköping are clear in both heat maps. On the other hand, the regions around Malmö and Uppsala, which are clearly visible in the growth map, do not appear as clusters of population decrease in the shrinkage map. This suggests that in the Malmö and Uppsala regions, where the population increased substantially from 2008 to 2017, population decrease did not occur in any part of the urban region. Norway is distinctively different from the other countries, in that there are very few noticeable clusters of population decrease. The reason for why some of the previously discussed examples in Denmark, Finland and Sweden appear as concentrations of population growth and population shrinkage at the same time seems to be that even the most rapidly growing city regions tend to include neighbourhoods with decreasing populations. This might be expected, for example, in areas where there has not been any new housing construction and where the average household size has decreased.
This could explain why certain areas stand out as concentrations of population decrease, even in regions undergoing substantial population growth.

Figure 4 includes a second category of shrinking places: those clearly recognizable in the shrinkage but not in the growth map. These are regions, cities or towns that are actually shrinking, without any noticeable population increase that would have had a counterbalancing effect. In Sweden, these shrinking places are primarily located in the northern parts of the country, where the Arctic cities of Kiruna and Gällivare are particularly visible. In Finland, the regions around Salo, Pori, Forssa, Kouvola, Savonlinna, Varkaus, Kajaani, Kemijärvi and Tornio are examples that stand out as concentrations of population decrease without any population increase in the growth map. Compared with Sweden, these areas of population shrinkage are more evenly spread throughout Finland, including in the southern parts of the country. In Denmark, highly noticeable concentrations of population shrinkage can be identified in Lolland (see also Figure 7) as well as in the southern, western and northernmost parts of Jylland. Norway differs considerably from the other three countries in that it has very few areas of substantial population shrinkage.

\subsection{The relationship between population development at the municipal and grid levels}

The focus in the following section is on the relationship between population change at the municipal level and that at the more detailed grid level. As mentioned in the previous section, although population growth and shrinkage can be viewed as opposite tendencies, these may still occur in the same region or city. The extent to which changes in the local grid level are reflected in broader municipal-level data, or the possibility of contradictory development tendencies, is explored here.

In general terms, population change at the grid level appears to be consistent with the development indicated by municipal-level data; this is evident in Table 8. The share of growing grid cells is, as expected, greatest in the municipalities that have experienced significant population growth. Similarly, the share of shrinking grid cells is proportionately the highest in "significantly shrinking" municipalities. This general situation applies to each of the four countries (see Appendix Tables). Nevertheless, it should be noted that in many growing municipalities, there are substantial shares of grid cells that 


\begin{tabular}{|c|c|c|c|c|}
\hline & $\begin{array}{l}\text { Growing } \\
\text { grid cells }\end{array}$ & $\begin{array}{l}\text { Shrinking } \\
\text { grid cells }\end{array}$ & $\begin{array}{r}\text { Entirely } \\
\text { unchanged } \\
\text { grid cells }\end{array}$ & $\begin{array}{r}\text { Highly sparse } \\
\text { grid cells }\end{array}$ \\
\hline $\begin{array}{l}\text { Significantly growing (population } \\
\text { increase of } 5 \% \text { or more) }\end{array}$ & $46.4 \%$ & $37.7 \%$ & $7.2 \%$ & $8.7 \%$ \\
\hline $\begin{array}{l}\text { Moderately growing (population } \\
\text { increase between } 2 \% \text { and } 5 \% \text { ) }\end{array}$ & $39.4 \%$ & $42.3 \%$ & $8.1 \%$ & $10.2 \%$ \\
\hline $\begin{array}{l}\text { Stable (population change between } \\
-2 \% \text { and } 2 \% \text { ) }\end{array}$ & $35.7 \%$ & $44.1 \%$ & $8.3 \%$ & $11.9 \%$ \\
\hline $\begin{array}{l}\text { Moderately shrinking (population } \\
\text { decrease between } 2 \% \text { and } 5 \% \text { ) }\end{array}$ & $29.6 \%$ & $45.8 \%$ & $8.5 \%$ & $16.1 \%$ \\
\hline $\begin{array}{l}\text { Significantly shrinking (population } \\
\text { decrease of } 5 \% \text { or more) }\end{array}$ & $21.0 \%$ & $46.2 \%$ & $9.3 \%$ & $23.5 \%$ \\
\hline
\end{tabular}

have decreased in population. Similarly, municipalities with substantial population shrinkage often include some growing grid cells. For example, more than one-third (37.7\%) of the grid cells in "significantly growing" municipalities in Denmark, Finland, Norway and Sweden have experienced a decrease in population. At the same time, approximately onefifth $(21 \%)$ of the grid cells in "significantly shrinking" municipalities have increased in population. Even though the dynamics of population change at the municipal and grid levels are generally in line, changes in population data at different geographic scales do not automatically mirror each other. Most growing municipalities are not uniformly growing, and most shrinking municipalities are not solely composed of shrinking areas. Table 8 also shows that the share of highly sparse grids, those with only one or two inhabitants in both 2008 and 2017, is proportionately much greater in shrinking than in growing municipalities. This reinforces the prior observation that municipalities undergoing population shrinkage more often encompass sparsely populated rural areas, whereas growing municipalities tend to be more densely populated.

\section{Zooming in on municipalities exhibiting particular population change dynamics}

The connection between population changes that have occurred at the municipal and grid levels between 2008 and 2017 is explored in more detail through municipal examples from Denmark, Finland, Norway and Sweden, including a diversity of small and medium-sized towns and their hinterlands having substantial variation in population size, population density and land area. Three specific types of municipalities have been selected based on their municipal-and grid-level population changes: first, municipalities that had a notable population increase, but where a large proportion of the geographical area (a high number of grid cells) decreased in population (category 1); second, municipalities where there was little change in overall population, but where considerable changes occurred at the grid level (category 2); and third, two different types of shrinking municipalities-those in which most of the grid cells within the municipality have decreased in population, and those with a proportionately high number of growing grid cells (category 3). Key characteristics of the population changes in the selected municipalities are presented in Table 9. The varying dynamics of population change in each of these municipalities are portrayed in Figures 5-7. Their locations are shown in Figure 1. 


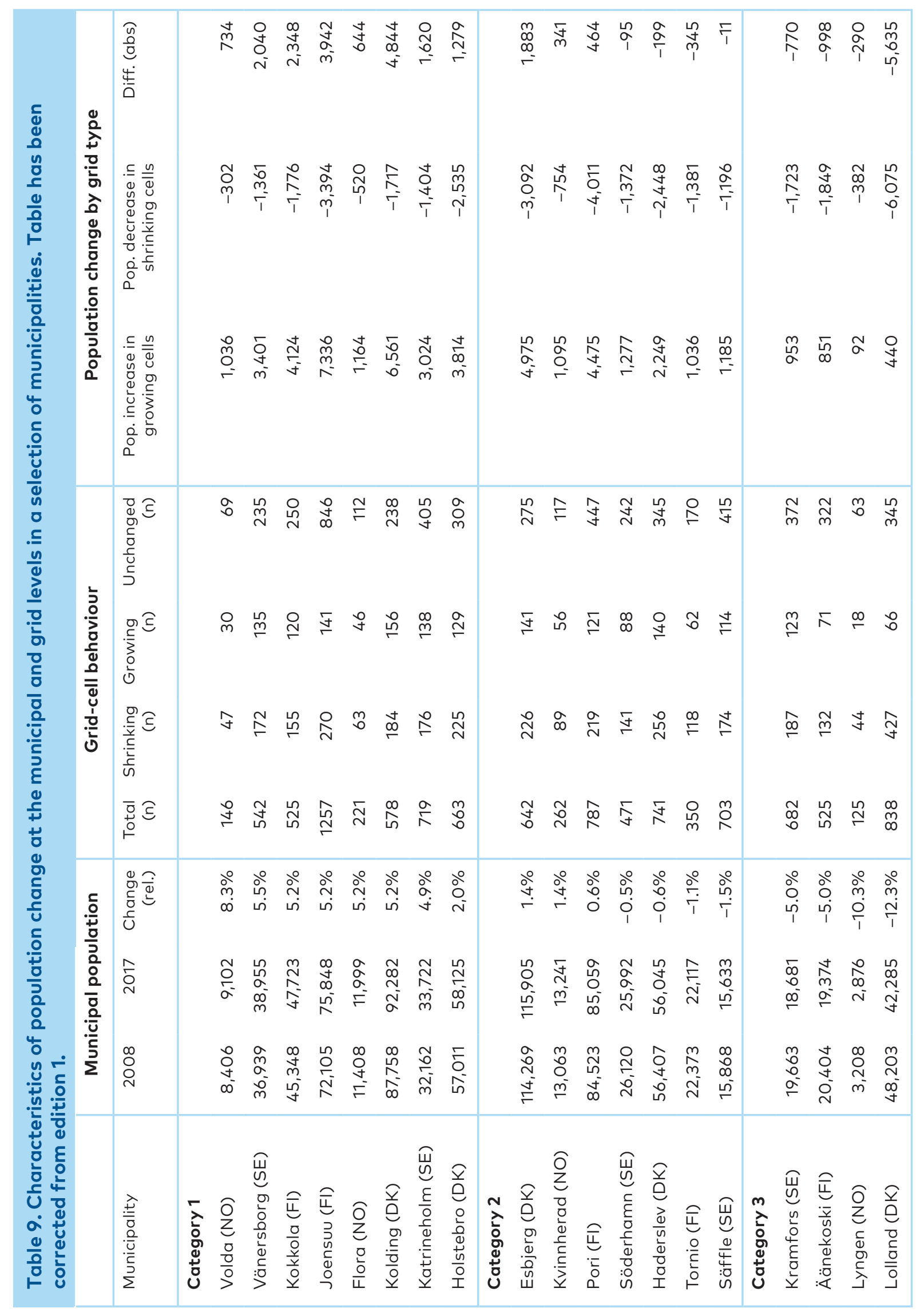




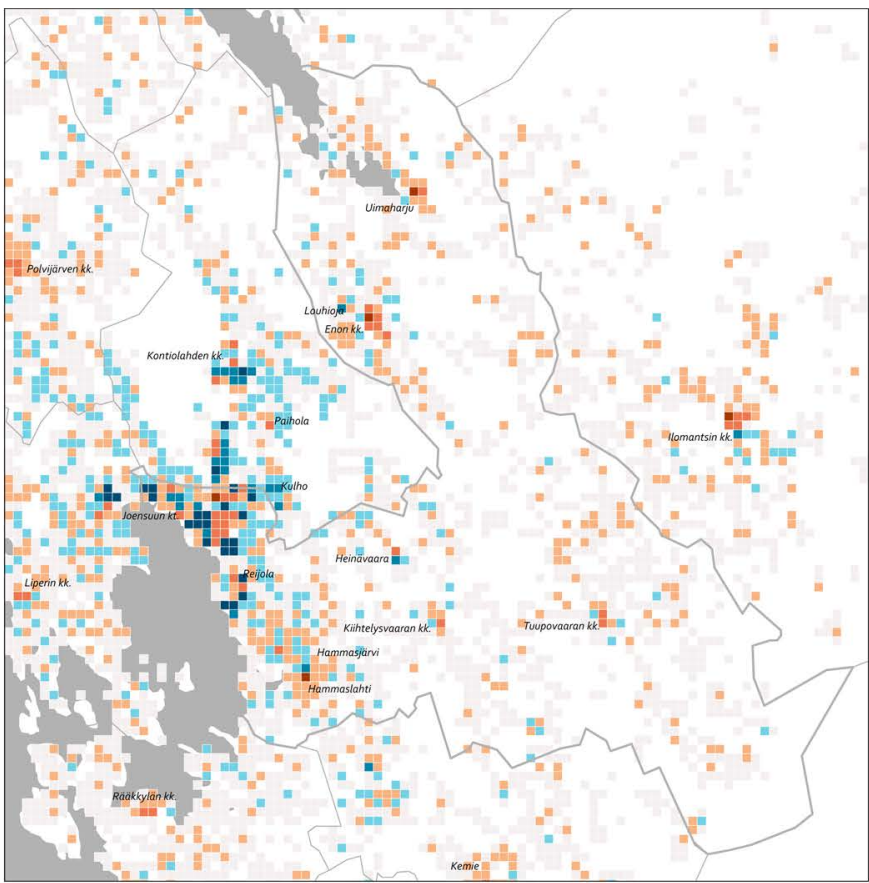

Joensuu

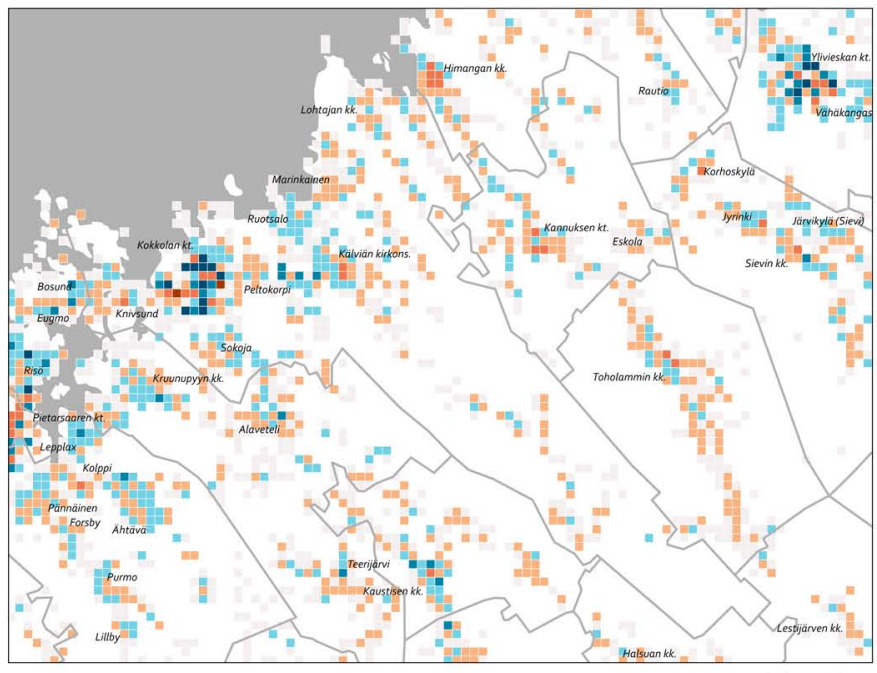

Kokkola
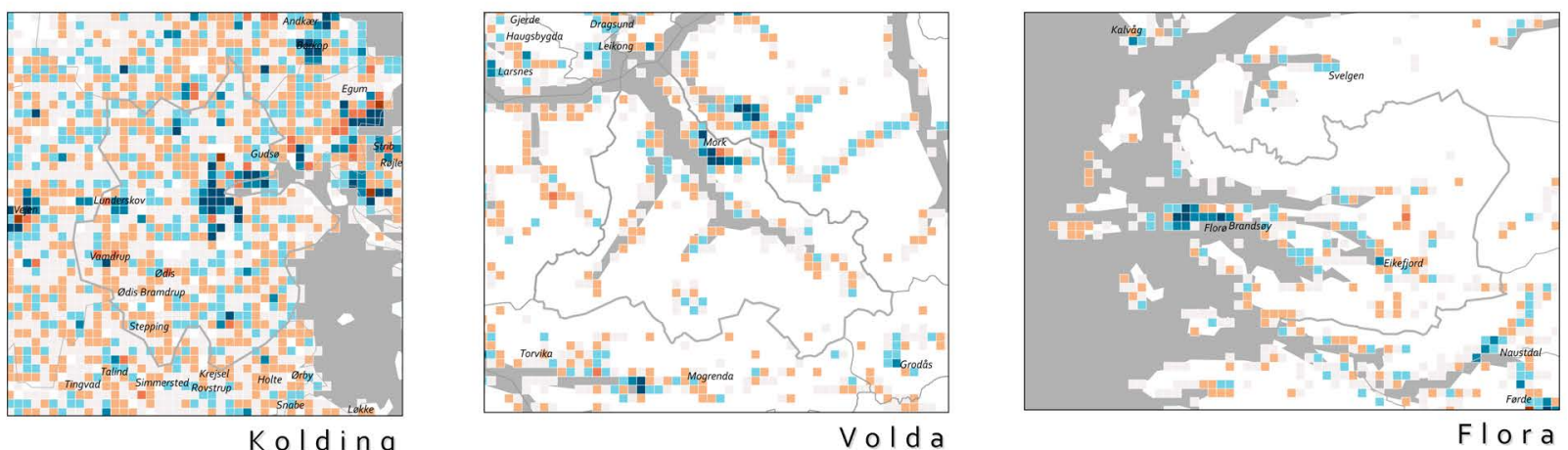

Population decrease

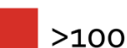

$25-100$

$3-24$

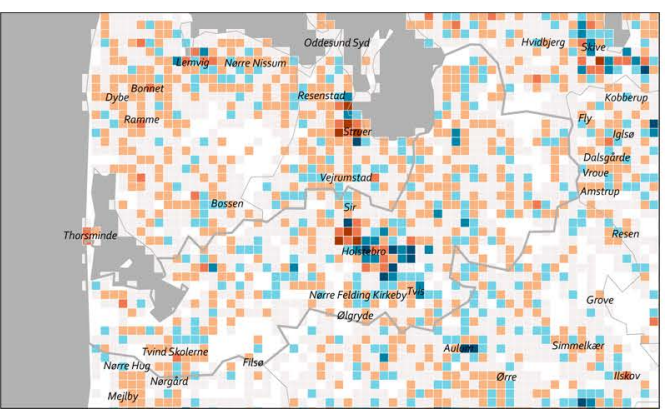

Holstebro

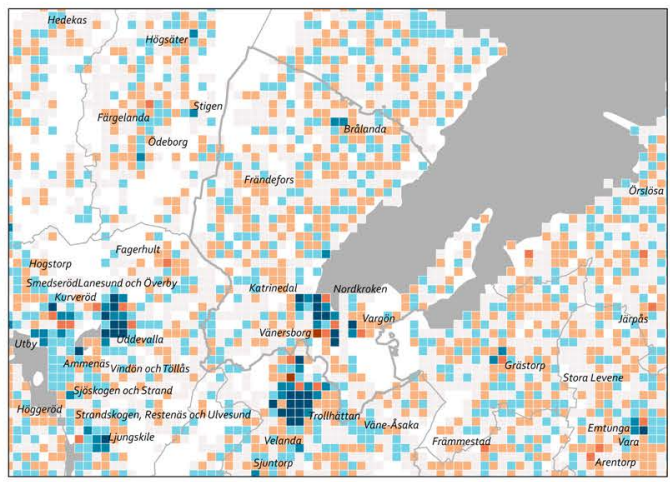

Vän ersborg

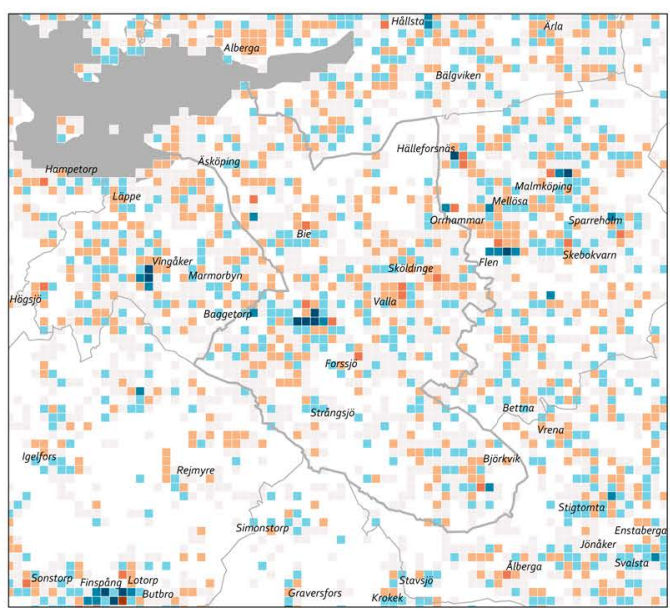

Katrineholm

Figure 5. Distributions of population change in a selection of growing municipalities that have a proportionately high share of shrinking grid cells (category). Maps by Oskar Penje. 


\section{A closer look at population change occurring within municipalities}

Figures 5-7 show the degree of population change (increase and decrease) within a selection of Nordic municipalities and parts of their neighbouring municipalities. These examples represent three different types of municipalities defined by population changes between 2008 and 2017 at the municipal compared with the grid level. Each figure shows municipalities belonging to one of the three categories. A more detailed view of these examples can be obtained by zooming in on these maps.
Figure 5 shows eight examples of category $1 \mathrm{mu}$ nicipalities-those with notable population increases (2008-2017) at the municipal level, but with a comparatively high share of shrinking grids, suggesting highly unbalanced development. There are two examples from each of the four countries. Holstebro, in Denmark, had a relatively moderate population increase of around $2 \%$, while the rest of the municipalities had increases of around $5 \%$ or more (Table 9).

The two Finnish examples displayed in Figure 5 are Joensuu and Kokkola (as well as parts of their neighbouring municipalities). At the municipal level, both Joensuu and Kokkola have experienced a significant population increase of around $5 \%$ but both municipalities are also characterized by more shrinking than growing grid cells, meaning that there are more areas within the municipality that are witnessing population decrease than increase. In Joensuu, in particular, the number of shrinking grid cells (270) is nearly double that of growing grid cells (141). Both Joensuu and Kokkola are relatively large municipalities and include wide areas that are very sparsely populated or uninhabited. Even though there are clearly more shrinking than growing grid cells in each municipality, the degree of population change has been significantly greater in the growing than in the shrinking grid cells. For instance, in Joensuv, the population increased by around 7,300 people in the growing grid cells, whereas it decreased by around 3,400 in the shrinking grids cells, despite there being significantly more shrinking than growing grid cells (Table 9). This suggests that the population is becoming increasingly concentrated in both Joensuu and Kokkola. In both cases, the most densely populated municipal centres have grown the most, although both these centres also include certain parts where the population has decreased. In addition, there are smaller secondary urban settlement centres located near the municipal centres that have witnessed significant increases in population. For instance, in the case of Joensuu, the neighbouring municipality of Kontiolahti had a substantial increase in population between 2008 and 2017. In particular, the main municipal centre of Kontiolahti has also had substantial population growth. As the main centre of Kontiolahti is within commuting distance of Joensuu, its growth appears to be related to the growth of Joensuu as the largest urban region in eastern Finland. By contrast, population decreases in both Joensuu and Kokkola are more dispersed, and largely occurred in remote and sparsely populated areas. In Joensuu, population decrease also occurred in some more densely populated areas located in the remote northern and eastern parts of the municipality (such as in Eno, Uimaharju and Tuupojärvi). It is noteworthy that many of the areas with the most pronounced population shrinkage were formerly located in separate municipalities prior to the merger of Joensuu with four neighbouring municipalities in 2005 and 2009.

Holstebro and Kolding, as well as parts of their surrounding municipalities, are the two examples from Denmark in Figure 5. Both municipalities increased in population, with substantially greater increases in Kolding (5.2\%) than in Holstebro (2.0\%). Both cases have a comparatively high share of shrinking grids: in Holstebro, the number of shrinking grids is nearly double that of growing grids. Both Holstebro and Kolding are substantially more densely populated, in line with the general settlement patterns in Denmark, than the examples from the other countries. However, the spatial patterns of population increase and decrease look somewhat different in these two cases. In Kolding, the main municipal centre mainly consists of grids that have experienced a substantial population growth of more than 100 persons, whereas the other parts of the municipality consist mainly of a patchwork of moderately growing and shrinking areas. In Hol- 
stebro, the municipal centre is where both the most substantial population increases and decreases have occurred; other parts of the municipality are a mosaic of more modest population increases and decreases.

The two Norwegian examples displayed in Figure 5 are Flora and Volda, located on the western coast of the country. Both cases had substantial population increases at the municipal level, are sparsely populated and had total populations of only around 12,000 and 9,000, respectively, in 2017. Both municipalities have approximately $50 \%$ more shrinking than growing grid cells, despite the relatively substantial population increase at the municipal level. In both Flora and Volda, the population has become increasingly concentrated, as the main municipal centres have undergone noticeable population growth, whereas the more remote parts of the municipality are characterized by population decease.

Katrineholm and Vänersborg are the two Swedish examples shown in Figure 5. Both municipalities had substantial increases in population of around $5 \%$, and both municipalities have a slightly higher proportion of shrinking than increasing grids. In both Katrineholm and Vänersborg, the shrinking grids had population decreases of around 1,400 people, whereas the growing grids had population increases of more than 3,000 people. In both cases, the most substantial population increases occurred in the main municipal centres. The main centres are surrounded by more sparsely populated areas, which are characterized by a mix of moderately growing and shrinking grids, albeit with a slight predominance of shrinking grids. These results also indicate that the populations are becoming increasingly concentrated.

The second category of municipalities experienced only minor changes in total population size between 2008 and 2017 (between -2\% and 2\%), but had noticeably more decreasing than increasing grid cells. In this regard, these municipalities are deceivingly stable, as substantial population changes can be observed at the grid level despite the overall population size remaining relatively unchanged. A characteristic feature of these municipalities is that they contain areas of both population increase and decrease. Seven examples of municipalities of this type are displayed in Figure 6.

Two examples from Denmark are displayed in the map, the municipalities of Haderslev and Esbjerg. Both had very similar populations in 2008 and 2017:
Haderslev with around 56,000 people and Esbjerg with around 115,000 . Despite this stability at the municipal level, both municipalities had substantially more shrinking than growing grids, meaning that most areas within the municipalities have experienced a decrease in population. In the case of Haderslev, the population in the shrinking grids decreased by approximately 2,400, whereas that in the growing grids increased by around 2,200 (see Table 9). These parallel changes of population, both increases and decreases, took place in different parts of the municipality and have balanced each other out, leaving the overall population size of the municipality largely unchanged. In both Haderslev and Esbjerg, the most noticeable increase in population was in and around the main urban centres, while the remainder of each municipality has been predominantly shrinking. As in many of the previous examples, the development patterns seen in Haderslev and Esbjerg suggest an increased concentration of population within the densely populated centres.

The Finnish municipalities of Pori and Tornio and parts of their surrounding municipalities are also mapped in Figure 6. Both had little change in overall population size, but had nearly twice as many shrinking as growing grid cells; however, the balanced population changes have resulted in overall stability in each case. Pori, the most densely populated urban centre, includes areas where substantial population increase has occurred, but also areas of notable population decline. Grids with a population increase of more than 100 people are presumably places where new housing construction has taken place, while population decreases in parts of the main centre are likely to be the result of a decrease in household size, and consequently, a shrinking population in certain neighbourhoods. The other Finnish example, Tornio, is located along the Swedish border and adjoins the Swedish town of Haparanda. As in Pori, the main municipal centres of Tornio and Haparanda appear as a mosaic of growing and shrinking grids. In both Pori and Tornio, areas outside of the main centres have primarily experienced population decrease.

The two Swedish municipalities presented in Figure 6 are Söderhamn and Säffle. There was relatively little change in the population size of these municipalities between 2008 and 2017: their total populations remained around 26,000 and 16,000, respectively. Despite this general stability in total population size, both municipalities include substantially more shrinking than growing grids. In 

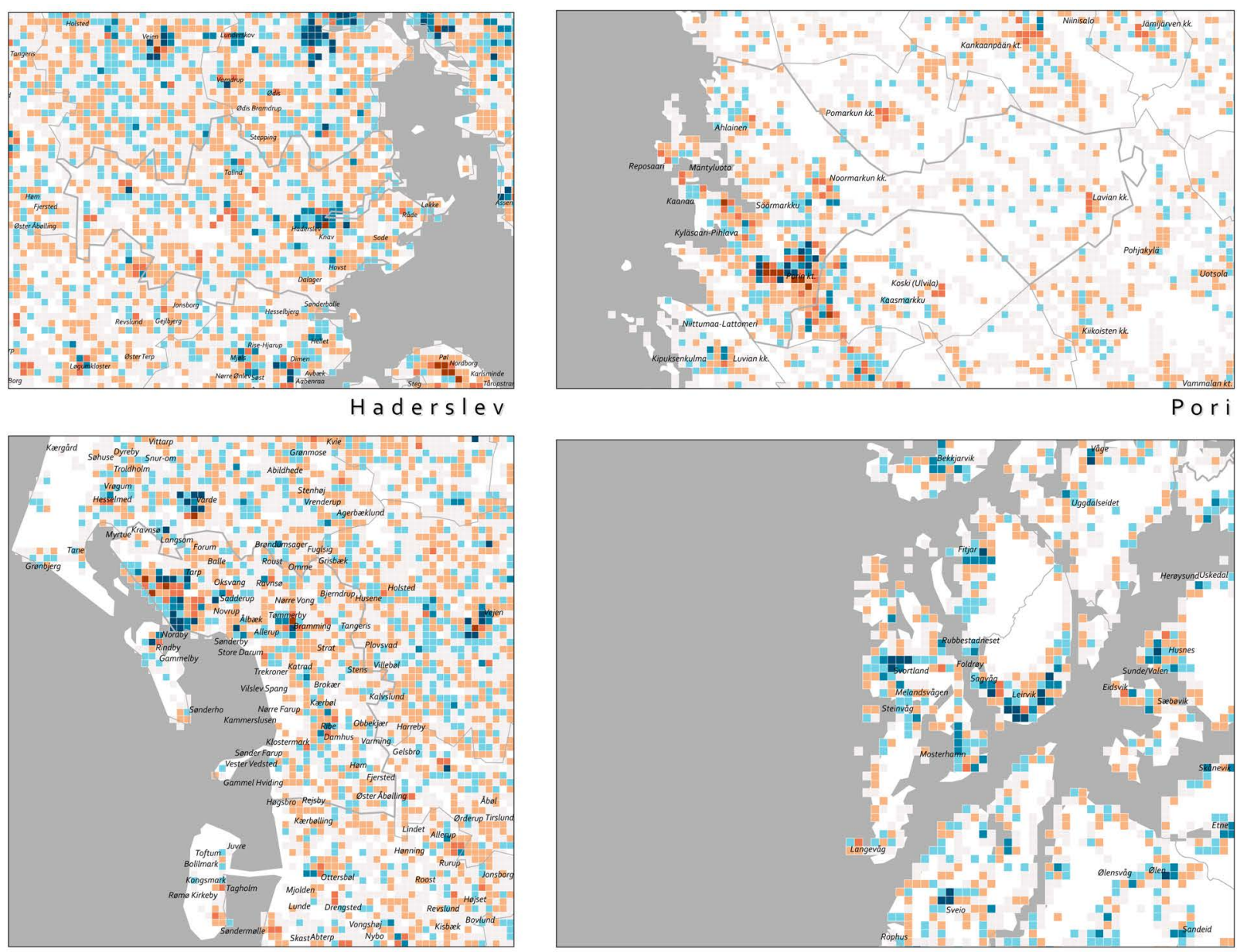

\section{Es bjerg}

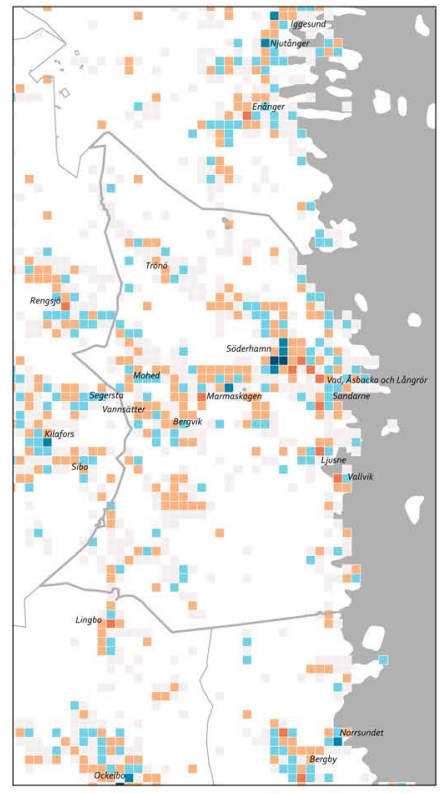

Söderham n

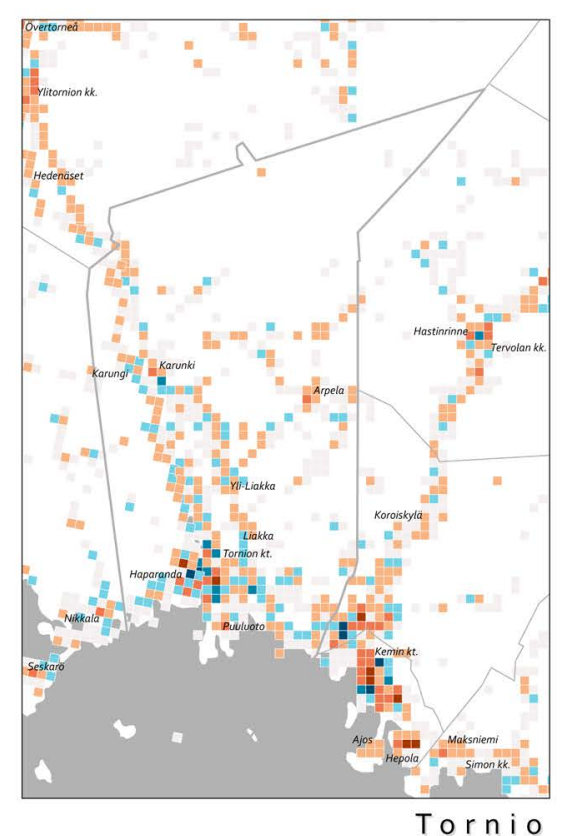

Tornio
Population decrease

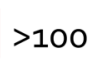

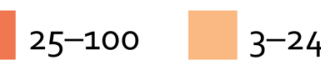

Population increase
Kvinnherad

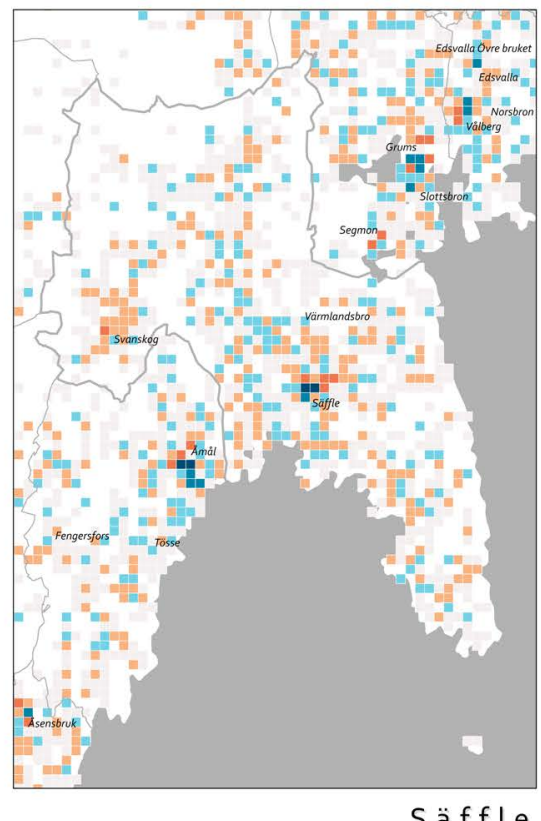

$S$ äffle

Figure 6. Distributions of population changes in a selection of stable municipalities that have clearly more shrinking than growing grid cells (category 2). Maps by Oskar Penje. 
Söderhamn, the main municipal centre had a notable population increase, whereas the rest of the municipality predominantly consists of areas with slight decreases in population. In Säffle, the municipality is primarily a mix of areas that have undergone population increases and decreases. The main town centre of Säffle has also experienced both increases and decreases, whereas the second largest urban settlement, Svanskog and its surrounding areas, is composed almost entirely of shrinking grids.

The Norwegian municipality of Kvinnherad is the final municipality mapped in Figure 6 . This municipality had a population of around 13,000 ; this has hardly changed, only $1.4 \%$ between 2008 and
2017. Kvinnherad consists of 89 shrinking compared with 56 growing grids. The map illustrates that the population mainly lives in coastal areas, while the inner parts of the municipality are largely uninhabited. The population changes within the municipality include notable increases in the main settlement areas, but decreases elsewhere.

The four examples displayed in Figure 7 depict four different municipalities that experienced a substantial decrease in population between 2008 and 2017 (category 3). The largest population shrinkages occurred in the Danish municipality of Lolland ( $12 \%$ decline) and the Norwegian municipality of Lyngen (10\% decline). In both the Swedish municipality of Kramfors and the Finnish municipality of
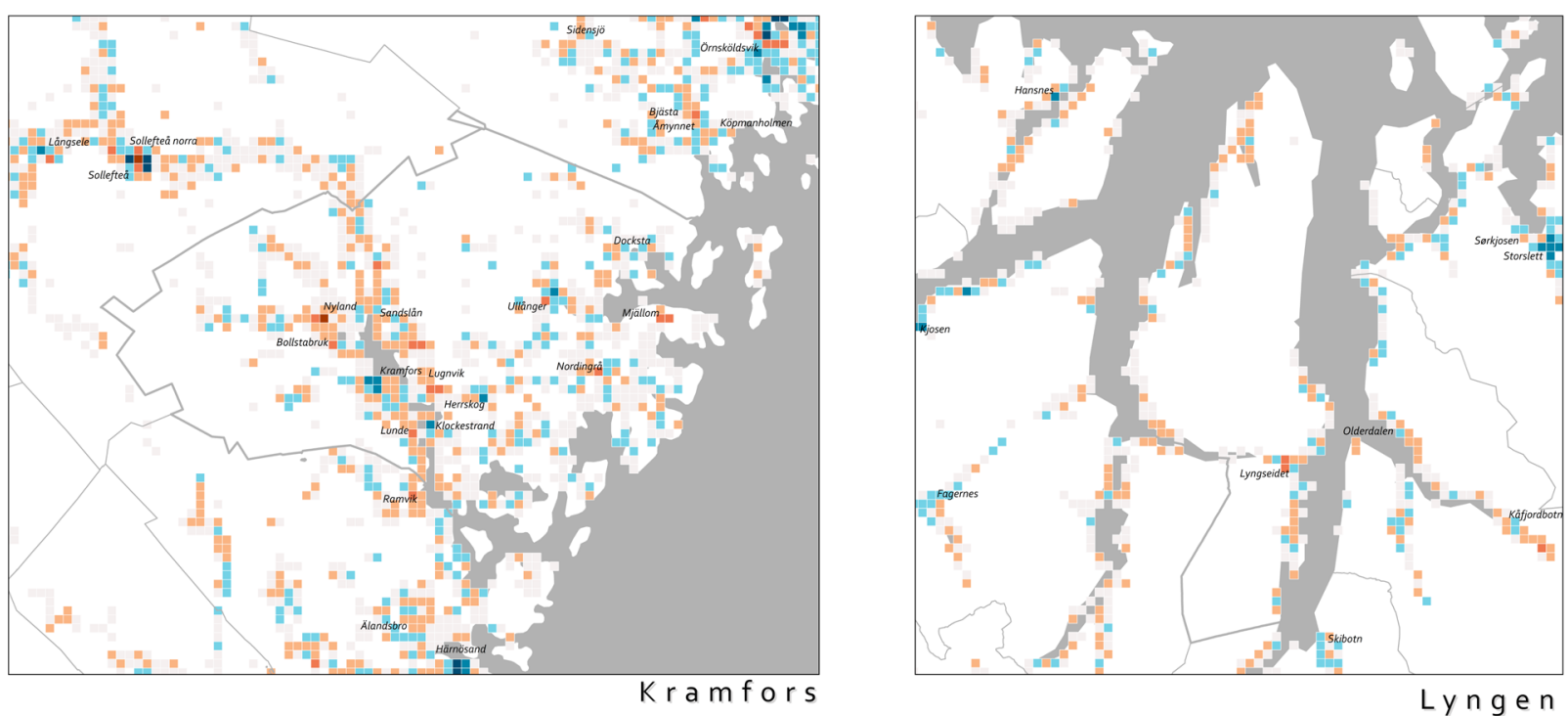

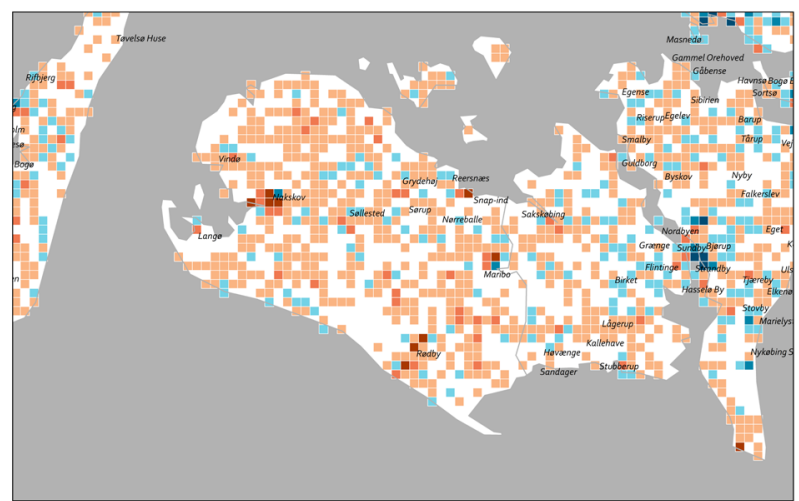

Lolland

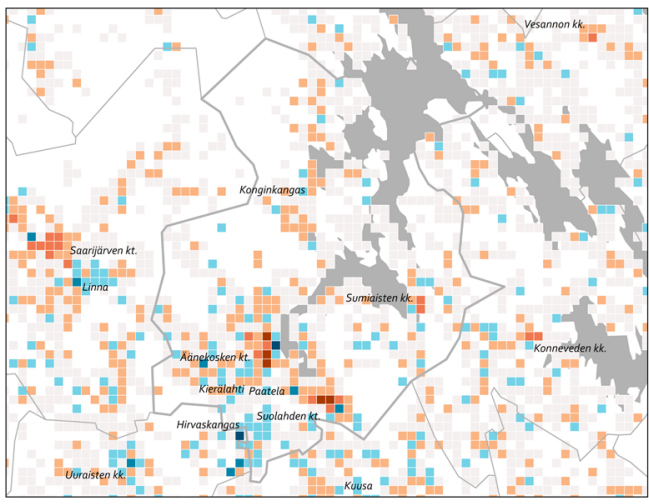

Ä änekoski

Population decrease

$>100$ $25-100$ 3-24

Population increase

Figure 7. Distribution of population changes in a selection of different types of shrinking municipalities (category 3). Maps by Oskar Penje. 
Äänekoski, the population decreased by approximately $5 \%$. Although all four populations decreased substantially, they represent two different types of shrinking municipalities. In Lolland and Lyngen, the clear majority of grid cells have experienced a loss in population, whereas Kramfors and Äänekoski have a comparatively high share of growing cells.

Almost all Nordic municipalities with population shrinkage of more than $10 \%$ have populations of less than 10,000; they are generally sparsely populated and predominantly rural. Lolland, with a population that decreased from over 48,000 to 42,000 between 2008 and 2017, is a unique case having a substantially greater population compared with other significantly shrinking municipalities. Lolland had a clear dominance of decreasing grid cells, outnumbering increasing grid cells by 427 to 66 . The shrinking grid cells lost more than 6,000 people, while the population increase in the growing grid cells was only around 400 . The predominance of shrinking grid cells in Lolland is apparent in all parts of the municipality, including the more densely populated urban areas such as Nakskov and the more sparsely populated areas outside of the urban centres. In Lolland, shrinking grid cells cover vast and continuous areas, and the overall population decrease has been significant in this clearly visible shrinking region (Figures 3 and 4).

The Arctic Norwegian municipality of Lyngen also had substantial population shrinkage and, similar to Lolland, had a predominance of grid cells that decreased in population. However, Lyngen, with a population that has decreased from approximately 3,200 to 2,900 , clearly has the lowest total population of all the examples examined in this section, and is by far the most sparsely populated. Most of the municipality of Lyngen is uninhabited, and the population is clustered in a few coastal areas. The population decreased in a majority of grid cells (44), whereas it slightly increased in 18 . The shrinking grid cells lost nearly 400 people, while the growing cells had a population increase of nearly 100 people. In Lyngen, the most substantial population shrinkage was in the main centre of the municipality, but the map makes clear that most areas in the municipality that are not entirely uninhabited decreased in population.

A different type of shrinking municipality is represented by the two other municipalities in Figure 7, namely Kramfors on the eastern coast of Sweden, and Äänekoski in central Finland. Both municipalities witnessed a rather significant drop in popula- tion between 2008 and 2017, but, compared with Lolland and Lyngen, these two cases contain a greater number of areas that have increased in population. These two shrinking municipalities are undergoing unbalanced development-opposite processes of population shrinkage and growth are evident-whereas Lolland and Lyngen are primarily composed of shrinking areas.

Kramfors and Äänekoski are very similar in terms of population change and size; both had relatively substantial population decreases from 20,000 to 19,000 , around $5 \%$ in each case. Corresponding to the changes at the municipal level, both Kramfors and Äänekoski have clearly more shrinking than growing grids, but the number of growing grids is nevertheless relatively high compared with Lolland and Lyngen. In Kramfors, especially, there were 123 growing compared with 187 shrinking cells. The growing cells increased by nearly 1,000 people, while the shrinking cells dropped by around 1,700 . In the map, Kramfors appears as a mosaic of decreasing and increasing grids, and the main centre of the municipality contains both population increase and decrease. The second most populated area in the municipality of Kramfors is the secondary centre of Bollstabruk, which stands out as a place of profound shrinkage.

In Äänekoski, there are almost twice as many decreasing (132) as increasing grid cells (71). The decreasing grid cells lost around 1,850 people, while the increasing cells grew by over 850 . A noticeable feature in Äänekoski is that both the main centre, in the south-west of the municipality, as well as the secondary centres, are predominantly composed of areas that have decreased in population. Meanwhile, a relatively high number of grid cells in the areas surrounding the main centre of Äänekoski have increased in population; this suggests an opposite line of development from most of the previous examples. Instead of an increasing concentration of population, these developments seem to be indicative of urban sprawl, where the most densely populated areas in the municipality are losing population, while certain more sparsely populated areas located near the main municipal centre have seen an increase. A similar situation can be seen in the neighbouring municipality of Saarijärvi, located west of Äänekoski, where the main centre of the municipality has seen a sharp decrease in population, while certain surrounding areas have grown.

In summary, this part of the analysis has presented examples of different Nordic small and 
medium-sized towns where the dynamics of population change do not reflect the overall changes in the municipality. These examples provide a more nuanced understanding of intra-municipal population changes that are not evident at more generalised levels of analysis. The focus has been on 19 examples exploring three different municipal categories; these illuminate certain common development tendencies. In particular, most municipalities are witnessing unbalanced development, where areas of population increase and decrease can be seen within the same municipality, even in cases where the municipality at large is undergoing substantial population growth or shrinkage. As Figures 5-7 illustrate, this unbalanced development is manifested in a mosaic of growth and shrinkage. The most common tendency is for the population to be increasingly concentrated, with the most no- table population increases occurring in the main urban centres. Surrounding, more sparsely populated areas are typically witnessing population decline. On the other hand, an opposite tendency of urban sprawl can also be observed. For instance, in Äänekoski, the urban centre has significantly decreased in population, while more sparsely populated areas near the centre have grown. From a planning and governance perspective, the unbalanced development occurring in many Nordic municipalities is a challenge; these municipalities are, in some cases, composed of vastly different areas following different lines of development. The mapped examples show that there is great complexity in the dynamics of population change across the Nordic region. It is likely that even greater diversity would be found through an analysis of a larger selection of municipalities. 


\section{Conclusions}

This study explored the use of fine-grained, gridlevel statistics from various Nordic countries regarding how they can be integrated and used for comparative analyses of phenomena and developments within regions, municipalities and cities. Empirical analysis was used to examine the dynamics of population change. The findings demonstrate that grid-level statistics can be used as a complement to municipal-level data to reveal trends that are less apparent, or not evident at all, at less spatially detailed levels of analysis. A specific aim was to understand the changes taking place within municipalities, especially in small and medium-sized cities, and to shed light on the following three questions:

What types of population dynamics occurred in the Nordic countries at the municipal and grid levels during 2008-2017?

- To what degree do changes at the local level correspond to more general population development at the municipal level?

- What types of changes can be seen within municipalities, especially in small and medium-sized cities?

Overall, the Nordic Region is undergoing highly unbalanced population development, and there are notable differences in demographic trends both between and within countries. Population shrinkage is clearly more widespread in Finland, at both the municipal and grid levels, than in the other countries. In Sweden, growing municipalities clearly outnumber shrinking municipalities, but a clear north-south divide can be observed within the country; the southern parts of Sweden consist almost entirely of rapidly growing municipalities, while the sparsely populated northern parts of the country have typically decreasing populations. A distinctive feature of Norway is that population shrinkage is less common compared with the other countries, and, unlike in the northern parts of Finland and Sweden, there are several municipalities and towns in northern Norway where the population increased noticeably between 2008 and 2017. In Denmark, most municipalities have witnessed an increase in population, but certain parts of the country, especially Lolland and the western parts of Jylland, have had notable population shrinkage. It is noteworthy that grid-level statistics show that most of the Danish territory has decreased in population, even though the populations of the majority of municipalities are growing; this indicates an increasing concentration of population. While Iceland was not included in the grid-level analysis due to a lack of data, municipal-level statistics demonstrate that the country has highly unbalanced development with high numbers of both "significantly shrinking" and "significantly growing" municipalities.

Urbanization is a global megatrend, and the analyses indicate that this is occurring in all four countries. While the population increased in Denmark, Finland, Norway and Sweden during the study period, the inhabited land area decreased. In each country, population increase is concentrated in urban regions, especially the capital city regions of each country, followed by other major and medium-sized urban areas. By contrast, population shrinkage is generally less concentrated and is most evident in sparsely populated and rural areas. Overall, the population in the Nordic countries is becoming increasingly concentrated. Within this overall trend, over the past decade, urbanization has been most profound in Finland.

Another key question concerned the relationship between changes observed from local data and those seen in more general municipal-level data. Might contradictory development tendencies be observed when comparing data at these two levels of aggregation? The analysis showed that population development at the grid level is generally in line with the broader development seen at the municipal level, with the share of growing grid cells highest in the municipalities that had significant population growth, and the share of shrinking grid cells highest in "significantly shrinking" municipalities. Nevertheless, growing municipalities are seldom entirely composed of growing areas, and most shrinking municipalities do not consist only of shrinking areas. Instead, opposite processes commonly occur in parallel within one municipality. These observations underline the fact that population increase and 
decrease are not mutually exclusive tendencies.

A more nuanced understanding of the various types of demographic changes that have occurred in small and medium-sized Nordic towns was provided by zooming in on a selection of examples. These examples highlight that many municipalities are experiencing unbalanced changes, which are manifested in a patchwork of growing, stable and shrinking areas within the same municipality. The general tendency seems to be that populations are becoming more concentrated, which could be considered to be related to the prevalent compact city ideal in the Nordics and how this possibly leads to a densification of housing in urban centres (see Tunström et al. 2018). On the other hand, there were also contrary areas where indications of urban sprawl, with population increase occurring outside of the urban core area, were observed.

All in all, population data at the grid level are a well-suited source of information for identifying demographic change processes and trends occurring within regions and municipalities. While this study examined changes in population size over time, it is evident that gridded statistics offer further potential. As further discussed in the Technical Considerations part, to fully realise the potential of grid level data at the Nordic level, further harmonisation of data processing and availability is required. 


\section{Annex: Technical Considerations}

This study relied on statistical data for examining population change across the Nordic Region during 2008-2017 with a specific focus on changes taking place within municipalities, and especially in small and medium-sized cities. Population change over time was analysed using statistical data on the municipal and grid levels from two separate years. Population changes that have occurred on the grid level were compared with changes evident at the municipal level. The grid-level data were complementary to the municipal-level data. Together, the two datasets allow a more nuanced understanding of the dynamics of population change compared with using municipal-level data alone. Specifically, grid-level statistics allow observation of phenomena and developments that are hidden at more general territorial levels. Throughout the course of this project, we have been guided by two main questions.

How can grid-level statistics from different Nordic countries be integrated in a way that allows for comparative analyses of phenomena and developments occurring within regions, municipalities and cities?

- How can fine-grained grid-level statistics be used as a compliment to more general statistics bound to administrative areas such as municipalities and regions?

During the initial phases of this project, a broad assessment of the availability of grid-level statistical data from the Nordic countries was carried out. Differences in availability in terms of variables, time series, reference dates, cell sizes and geographic projections were assessed. In most countries, dissemination of these data types by the national statistical institutes is entangled by various restrictions; these restrictions may be related to specific revenue models linked to data production or to confidentiality and disclosure policies, which can be a barrier for end-users outside academia. A brief overview of these different restrictions follows.
After this broad data overview, a data collection process led to the development of an integrated grid dataset with the expectation that this would provide insights into sub-municipal population change across the Nordic Region. As complete a Nordic coverage as possible at a uniform level of geographic aggregation with data from two reference years was sought. This required certain tradeoffs arising from a quest for uniformity ("a lowest common denominator"), while at the same time, maximising geographical coverage and keeping costs at an acceptable level. The resultant datasets have been analysed to provide insight into population change and dynamics within Nordic municipalities over the past 10 years. The results from these analyses are presented in the Main Report.

This Technical Considerations part provides a description of the data and the methodology used to meet the aims of the study, while also providing some context and argumentation related to the use of grid-level statistics more generally. This report is structured as follows. First, the concept of grid-level statistics is presented accompanied by a discussion about the advantages of using spatially detailed grid data compared with more general statistics aggregated at administrative levels. Second, an availability assessment of gridded population data from the Nordic countries is provided. Third, the work stages undertaken to create a uniform grid dataset by integrating grids from different reference systems is discussed. Fourth, an overview of the main challenges in harmonisation of grid data across the Nordic region is provided.

\section{Introduction to the concept of grid data}

Official statistics are traditionally produced according to a hierarchical system of administrative areas, ranging from local administrative units, such as neighbourhoods, districts or postal code areas, to the national level. For instance, in studies concerned with differences within countries, the most common point of departure is to analyse 
data at the regional or municipal level. Grid-level statistics, by contrast, have been geographically referenced to a system of grid cells rather than to administrative areas. Grid statistics are typically produced by first establishing point locations for all observations. In a subsequent step, and with the use of a geographic information system (GIS), these points are overlaid and aggregated ${ }^{2}$ into grid networks based on the location of the observations. The data can be aggregated into grids of any cell size. The Nordic countries produce grid-level statistics at a variety of grid levels (see below).

\section{Why grid data?}

When conducting spatial analysis, grid data offer several advantages compared with data aggregated to administrative areas. The most prominent advantage is that gridded statistics avoid the statistical bias referred to as the modifiable areal unit problem (MAUP). This bias may occur when observations are summarised to areal units with varying shapes and sizes, and with boundaries that are established from a rationale that is irrelevant to the aggregated observations. Boundaries may be based on a coalition of different factors (morphological, political, historical), which also means that they are subject to change ${ }^{3}$. This would mean that "a particular aggregation at a specific scale can yield an arbitrary result that is valid only for that specific delineation" (Hennerdal \& Nielsen 2016). Thus, the same data can produce different maps, as illustrated in Figure 1. In addition, the spatial divisions at a particular administrative level are usually established with some regard to population size, essentially striving to create units with similar populations. This means that low-density areas will generally be divided into larger units, while high-density areas will be divided into smaller units. While this has a clear logic from a governance perspective, it has some adverse implications when analysing population indicators. For example, it provides no sound basis for studying distance-related factors such as clustering and dispersion.

Another advantage of gridded statistics is that they can easily be integrated with other geographic

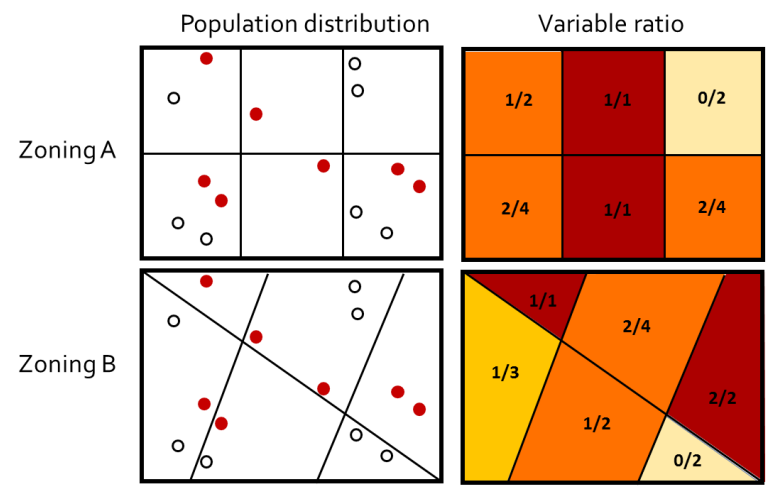

Figure 1 illustrates how the same geographical data can result in two different choropleth maps depending on the zoning logic ( $A$ or $B$ ). In this example, the white points represent observations, and the red points represent a specific variable for the observations. The geographic locations of the observations in map $A$ and map $B$ are identical, but they result in different maps when aggregated to different areas.

data, such as transport, land use, geological and climate data. The spatial units are uniform and constant, which means that they are well-suited for spatial analysis and provide better potential than administrative areas such as regions and municipalities, which may be affected by boundary changes, for studying changes over time. Since gridded statistics are generated without regard to the underlying geography, they also provide a good base for developing different types of typologies (e.g. of urban, rural and intermediate areas) based on the frequencies of the observations. Grid-level statistics can therefore be used to create typologies based on spatial statistics, and to create new statistics based on these typologies.

\section{MAIN ADVANTAGES OF USING GRID STATISTICS}

- Uniform and unisize - avoids MAUP and allows spatial analysis

- Not changing - allows analysis over time

- Integrates easily with other spatial data

2 Aggregation is the process of summarising smaller spatial units and the data they contain into larger spatial units and then joining the data together (Heywood et al. 2006: 412). 3 Actively adjusting administrative borders with regard to population structure can be used as a tool for political purposes (see Gerrymandering). 


\section{Nordic population grid}

In Europe, the Nordic countries have played a pioneering role in developing statistics at the grid level, as the first population grids were produced as early as the 1970s (Population Grids 2018). This is largely the result of a long tradition of maintaining residential statistics, as well as coordinate coding of properties and addresses in the Nordic Countries. While these types of registers are maintained and updated annually by all Nordic National Statistical Institutes (NSIs), only Denmark, Finland, Norway and Sweden produce grid-level aggregates for longer time series. Statistics Iceland has produced a register-based population grid only for $2011^{4}$, but this is not yet published.

In addition to the population data on the grid level that are widely available from Denmark, Finland, Norway and Sweden, grid-level statistics are also, to varying degrees, available on attributes of the built environment and housing stock, workplace structure, services and amenities, commuting distance and car ownership. In parallel with aggregating data to national grid systems, Denmark, Finland, Norway and Sweden have contributed data to the pan-European grid under the Eurostat GEOSTAT project.

The GEOSTAT project was initiated in 2010 as a collaboration between Eurostat and the European NSIs. The goal was to establish a uniform Europewide data and production infrastructure for geospatial statistics. The main achievement of the first project round was the development of a 1,000 $\times 1,000$-m grid with population data from the EU countries and the four EFTA countries for the years 2006 and 2011. The grid was generated using Inspire ${ }^{5}$ standards in the ETRS89/ETRS-LAEA projection. A full European coverage of population numbers by grid cell has been achieved with the use of two main methodologies. The primary methodology is "bottom-up" aggregation of geocoded microdata received by the NSIs; this was the method used for the vast majority of countries. The other is a "topdown" approach that involves disaggregation of statistics from local administrative units informed by land cover classifications derived from satellite imagery, essentially modelling population distri-

\footnotetext{
42011 was the year of the latest "Population and Housing Census"; this is also the year of reference for the pan-European GEOSTAT data.

5 INSPIRE - Infrastructure for Spatial Information in EUrope. Directive 2007/2/EC of the European Parliament and the Council of 14 March 2007.
}

bution within these administrative units based on generalised key figures. For some countries, a hybrid of these two methodologies was used. The accuracy of the figures at the grid level is clearly dependent on which of these methods is used. Some countries in which "bottom-up" data aggregation was used for 2011 data have only "top-down" data available for 2006. Only Austria, Sweden, Finland, Denmark and the Netherlands were able to deliver data based on the same spatial reference source (place of usual residence) for both reference years.

With their wide geographical coverage, the GEOSTAT data provide a solid base for analysis of population density distributions at a local level across Europe; these data are well-suited for regional classifications of different types. For instance, these data have been used by European environment agencies and Eurostat to classify municipalities by degree of urbanisation. They have also been used in the ESPON TOWN project as the primary data source for creating a classification of different categories of small and medium-sized towns in Europe (Servillo et al. 2014). However, because of methodological inconsistencies and (welldocumented) statistical deviations, these datasets are not well-suited to detect change at the gridlevel, which was a core objective of this project. These data were therefore treated as a last resort should no other data be available for one of the Nordic countries or territories. This was not necessary, as widely available grid-level statistics from the Nordic NSIs are clearly more accurate and reliable for studying population dynamics at the local level.

\section{Data collected for the report}

In addition to creating a grid dataset with as wide a Nordic coverage as possible, it was considered crucial that all data met the following criteria:

1. Data are available according to the same homogenous grid cell size from all countries and territories regardless of typology or population density

2. Population data are aggregated from microdata and not derived from modelled, or "top down," disaggregation

3. Data are available for the same two reference years for all countries and territories

These baseline criteria were fulfilled for Denmark, Finland (including Åland), Norway and Sweden. For Iceland, only the first and second criteria were 
fulfilled since at the time of finishing this report, the only statistical year available for Iceland was 2011. For the Faroe Islands and Greenland, none of the baseline criteria were met.

High-resolution grid data can be grouped to a more general level of aggregation, but data at a certain level cannot be made more detailed. This applies to geographical data, but it is also true when grouping variables. Advancing from the baseline criteria, we therefore strove to obtain data at the highest possible level of geographical resolution (smallest cell-size) shared by all countries, and also with the most detailed statistical breakdown available for variables concerning age and gender. Time and budget limitations within the project were also factors to consider during the data gathering process, favouring the use of open data when available. The highest harmonised level of spatial aggregation obtainable under these criteria was at the $1,000 \times 1,000-m$ grid level, which is the same size as the INSPIRE grid data. In terms of variable properties, unfortunately, no age or gender sub-categorisation could be included in the harmonised dataset due to national differences. The reference years for the study were set considering the open availability of Norwegian data, spanning a period of 9 years, from 1 January 2008 to 1 January 2017. The next section describes the national data, by country, in greater detail.

\section{Sweden}

The total population data for $1,000 \times 1,000-m$ grids were provided free of charge by Statistics Sweden (SCB) and are available from their web portal for the most recent reference year. Other variables or levels of aggregation can be purchased from SCB. The grid sizes currently available are $100 \times 100 \mathrm{~m}, 250 \times 250 \mathrm{~m}$ and 1,000 $\times 1,000$ $\mathrm{m}$. SCB also produces datasets combining grid sizes allowing different scales of analysis depending on population density. For instance, residents in urban settlements ("tätort") are aggregated to a $250 \times 250-\mathrm{m}$ grid, while residents outside of urban settlement areas are aggregated to a $1000 \times 1000-m$ grid. To prevent the disclosure and identification of individual residents, SCB applies a general scheme of removing grid cells with fewer than three residents.

Together with other Swedish state agencies, SCB also provides data free of charge for use by non-profit organisations under FUK-license agree- ment (Forskning, utbildning och kulturverksamhet) for purposes of research, education and culture. A broad range of gridded statistics are available under this license, including a range of socio-economic variables aggregated to the combined grid (composed of both $250 \times 250-\mathrm{m}$ and 1,000 $\times 1,000-\mathrm{m}$ grid cells), and total population at a cell size of 100 $\times 100 \mathrm{~m}$. The time series delivered under an FUKlicense varies, but generally has 2013 as the earliest statistical year. The quality of the Swedish population registries allows for data to be produced in long time series. Population data can be acquired for years as early as 1982.

Nordregio is part of the FUK-licence agreement; however, the data obtained through this agreement did not meet the baseline criteria in terms of grid size and reference years, meaning that data had to be purchased directly from SCB. The purchased data were delivered as two separate vector datasets (ESRI shapefiles) comprising the populated grids for each year, with attributed statistics. The data were then joined to a full grid covering the entire country (also including uninhabited areas), thus creating an integrated dataset allowing for longitudinal analysis of population change over time.

\section{Finland}

Regarding Finland, 1,000 × 1,000-m population data are provided free of charge for the whole Finnish territory (including Åland) through their Geoserver implementation. The reference years available through this service are 2006 and 20112017. The Finnish Grid Database also offers for purchase a broad range of other variables, including various demographic and socio-economic attributes and indicators related to housing, dwellings and workplace structures. The Finnish variables are provided on grids with cell sizes of 250, 1,000 or $5,000 \mathrm{~m}$. The earliest year for which data on total population can be produced, and where data quality is guaranteed, is 1990.

The open data for 2017 fulfilled the criteria to be used for the study, while data representing the situation in 2008 had to be purchased separately. Both reference dates were, in a subsequent step, matched to an empty grid with full national coverage. Due to inconsistencies in the unique identifier coding between the three datasets, they were consolidated using geographic matching instead of attribute-based matching. 


\section{Denmark}

Statistics Denmark produces a wide range of variables at the grid level. In general, all variables found at the municipality level in the statistical database can also be provided as grids. For data with disclosure restrictions, which is not the case for total population, Statistics Denmark has a clustering method by which each local cell value is normalised with the neighbouring cell values.

No gridded data are provided free of charge from Statistics Denmark; hence, both reference years had to be purchased for this project. The revenue model applied in Denmark for grid data is commercial; this results in a price that is four times as high as that in, for example, Sweden. The Danish statistics were delivered in the form of spreadsheets, while the vector data had to be generated using a GIS plug-in application. These datasets were matched using a unique ID code.

Grid-level statistics are not currently available for the autonomous territories of Greenland and the Faroe Islands.

\section{Norway}

Statistics Norway (SSB) produces annual statistics on different grids $(250 \times 250 \mathrm{~m}, 1,000 \times 1,000$ $\mathrm{m}$ and $5,000 \times 5,000 \mathrm{~m}$ ). Norway has the most grid data among the Nordic countries in terms of the variety of statistical variables, as well as in terms of time series and being open for public use and free of charge. Data covering the following four themes are found at the Statistics Norway website (with varying length in time series for different themes, but also depending on grid size): population data, building and property data, land use data and business data. Population data on a $1,000 \times 1,000-m$ grid are available from the SSB website for all years between 2008 and 2017. These data also include average age and population by gender. On request, these data can be acquired for each year stretching back to 2001. The Norwegian statistics are provided in spreadsheet format, which can be connected to a vector grid (also available online).

\section{Iceland}

Statistics Iceland has not made any decision to match population data to grids on a regular basis. At this point, only reference year 2012 has been gridded. This dataset, however, provides a breakdown on gender and by broad age groups.
Although grid data have been produced only for a single year (2012), the underlying coordinate points and matching registry data are maintained for every year since 2011. Apart from the technical procedure of aggregating these data, Statistics Iceland has not yet established a policy on confidential data disclosure. For the time being, this prevents them from publishing variables other than population aggregated to grids.

\section{Data consolidation}

\section{Municipality coding}

To be able to compare grid-level population change with changes at the municipal level, and to identify intra-municipal dynamics, a municipality identifier was included in all grid cells. Apart from in the Finnish data, municipality codes were not included in the grid datasets. A uniform coding logic was therefore applied to all country datasets (including Finland) using the cell centroids. This meant that a municipal code was transferred to a grid cell based on the location of the cell centroid. When population figures were later aggregated based on the grid coding, the summaries deviated from the official municipal statistics. This mismatch occurred because the grids sometimes geographically intersect municipality boundaries. When using our method of municipal coding, this causes a "misplacement" for some residents along these borders. This effect is generally larger in small municipalities with a dense population. For $90 \%$ of all Nordic municipalities, the deviation was less than $2 \%$ of the population totals, while for a few small and densely populated municipalities, usually in metropolitan regions such as Salem (SE) or Nittedal (NO), the differences ranged from $5 \%$ to $15 \%$.

\section{Data consolidation and visualisation}

By definition, a statistical grid is regular and uniform. It is abstract, i.e. detached from the underlying geography, which means that grid edges have no connection to geographic features or boundaries. Since they are automatically generated in a specified projected coordinate system (which is suitable for a specific country or region), they only maintain a geometric shape in that specific projection. This means that a re-projection of grid data will create some linear distortion, or deviation from the $90^{\circ}$ geometry. For information about projections, see the info-box below. 
Projection is the process of mapping geographic information from the spherical globe onto a flat surface. There are various types of projections, but they all distort the spatial relationship between locations to some degree. Normally, a projection is selected that minimises this distortion for a geographic area of interest, and also accords to the cartographic aim. The larger the geographic area to be mapped, the more evident the distortions will be in the projection.

The statistical grids from the Nordic countries are generated in national coordinate reference systems, which means that when they are consolidated and visualised at a pan-Nordic level, the grid lines do not run parallel over the entire coverage; the cells will appear "tilted" toward one or the other direction somewhere in the extended map (depending on which coordinate system is chosen for visualising the data). In Figure 2, map A shows how these data properties affect visualisation along the Finnish-Swedish border region around the Gulf of Bothnia. This difficulty is one of the key challenges when establishing common grid standards, such as the European Inspire grid, to be used over large territories. For countries that are located along the flanks of a grid coverage, such as Iceland, there is no option of transforming the data to a national projection without tilting the grids, such that the cells no longer appear square.

The 1,000 × 1,000-m grid may be too detailed when mapping the whole Nordic Region. Therefore, different ways of clustering and aggregating data were explored. For this purpose, a grid size of 5,000 $\times 5,000 \mathrm{~m}$ was found to be more suitable. The spatial relationship between these different grids are presented in Figure 2. Based on the location of centroids, the original grid cell population values were aggregated up to a 5,000-m grid in the CRS ETRS89-LEAE projection. Although this leads to additional dislocation of the population in relation to the original $1,000 \times 1,000-\mathrm{m}$ grid, the effect is negligible when visualised at the Nordic scale.

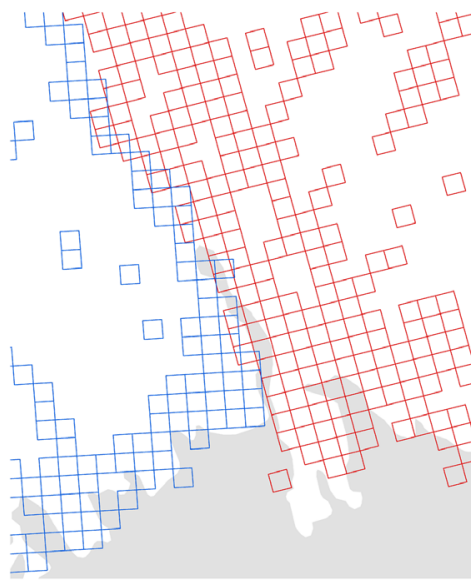

Figure 2

A) $A 1,000 \times$ 1,000-m grid from two different systems is displayed.

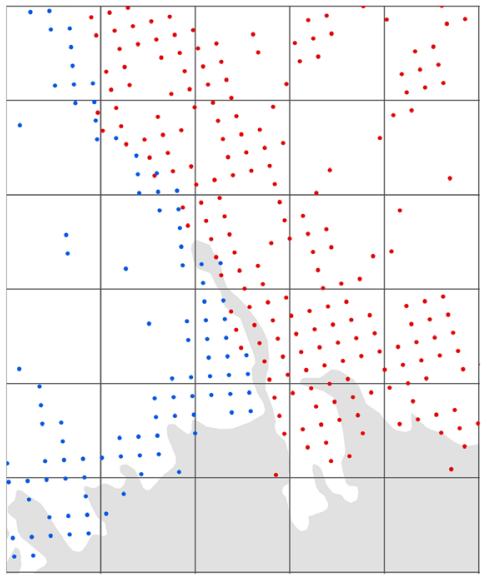

B) Population data from each grid cell were aggregated up to a $5000 \times 5000-m$ grid based on the locations of the centroid of each 1,000-m grid cell.

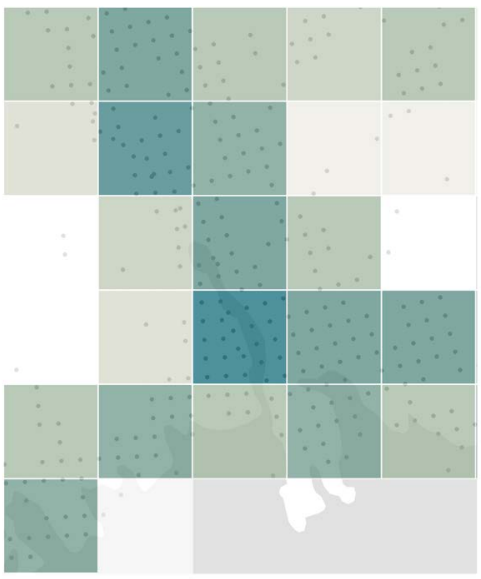

C) Choropleth visualisation based on classification of the frequency.

\section{Discussion}

As previously highlighted, a wide range of gridded statistical data is available from the Nordic countries. Although grid-level statistics on population are widely available from Denmark, Finland, Norway and Sweden, there are notable differences in the exact variables available from each country. For instance, while basic population data concerning population size, gender and age distribution are relatively similar in all countries, and can 


\begin{tabular}{l}
$\begin{array}{l}\text { Table 1. An example of differences in the classification of socio-economic variables } \\
\text { in the Finnish and Swedish grid datasets. }\end{array}$ \\
\hline Employment
\end{tabular}

generally be quite easily harmonised, there are greater differences in the available socio-economic variables. This poses a challenge for data harmonisation, as, for instance, employment, educational level and purchasing power are calculated according to different age groups in the Finnish and Swedish datasets (see Table 1). For example, harmonisation of level of education at the grid level is difficult because this variable is calculated according to the age group of 18 years and over in the Finnish Grid Database (2017), but for the age group of 25-64 years in the Swedish data (Market Profiles 2017).

With data at a high level of spatial resolution, there is a risk that the location of individual residents is disclosed, especially in sparsely populated areas; this can be an issue when socioeconomic indicators are involved. Therefore, all NSls in the Nordic countries use some kind of arrangement for preventing the disclosure of confidential information. Different approaches for ensuring non-disclosure pose further challenges to data harmonisation. In the Swedish data, for instance, grid cells with fewer than three residents are not included, meaning that it is not possible to differentiate between grid cells with zero, one or two inhabitants. In Finland, socio-economic variables (income, education and employment) are coded as -9 for confidentiality reasons if there are fewer than 10 individuals (of at least 18 years of age) recorded in a grid cell. In Norway, no data for socio-economic variables are made available, while in Denmark, a clustering method is used as a way of handling privacy issues.

Population data at the grid level are an excellent source of information for identifying demographic change processes and trends at the sub-municipal level. With gridded population data, these processes can be studied at the local level, and as a comparison between different typologies and regions or in relation to other local spatial factors. The potential of working with grid data for these purposes has been explored here in the Technical Considerations part. An overview of data availability from the Nordic countries has been provided, as well as a description of key steps in the processing and aggregation of the data. The Main Report presents examples that draw evidence-based conclusions about demographic patterns from these data.

As previously discussed, there are some notable differences between the Nordic countries in terms of how gridded population data are made available. Apart from these differences, there is great unity in regard to how underlying geodata should be built and maintained. Nordic countries have similar conventions when it comes to the systematisation and management of personal identification numbering, residential registry and other data associated with the individual. This unity of approach is of considerable benefit to the Nordic region, even in a European context. The analyses in the Main Report were possible due to the commonality of a relatively general variable, such as total population. When more variables are in wide and consistent use, there will be greater opportunities to study patterns in age groups or other population characteristics, thereby providing further insights into local dynamics and demographic potentials. Therefore, to fully realise the potential of population data at the Nordic level, further harmonisation of data processing and availability is needed. This, of course, should respect data confidentiality regulations and not risk the disclosure of individual information. 


\section{References}

Bell, D. \& Jayne, M. (2009). Small cities? Towards a research agenda. International Journal of Urban and Regional Research, 33(3), 683-699.

Bontje, M. \& Musterd, S. (2012). Understanding shrinkage in European regions. Built

Environment, 38: 2 (2012), 153-161.

Eurostat (2018). Population density, persons per $\mathrm{km}^{2}$. Eurostat. <https://ec.europa.eu/eurostat/ $\operatorname{tg} \mathrm{m} /$ table.do?tab=table\&init=1\&/anguage= en\&pcode $=$ tps00003\&plugin $=1>$ (accessed 20.12.2018)

Grid Database (2017). Grid Database 2017 - User Manual. Statistics Finland. <https://www. stat.fi/static/media/uploads/rttk2017_kuvaus_ en.pdf> (accessed 20.12.2018)

Grunfelder, J., Rispling, L., \& Norlén, G. (Eds.), State of the Nordic Region 2018. Nordic Council of Ministers.

Grunfelder, J. (2018). Nordregio Regional Potential Index 2017. Measuring regional potential. In Grunfelder, J., Rispling, L., \& Norlén, G. (Eds.), State of the Nordic Region 2018 (pp. 74-86). Nordic Council of Ministers.

Heleniak, T. (2018.) Migration, the wary welcome of new-comers to the Nordic Region. In Grunfelder, J., Rispling, L., \& Norlén, G. (Eds.), State of the Nordic Region 2018 (pp. 48-58). Nordic Council of Ministers.

Hennerdal P. \& Nielsen M. N. (2017). A Multiscalar Approach for Identifying Clusters and Segregation Patterns That Avoids the Modifiable Areal Unit Problem, Annals of the American Association of Geographers, 107:3, 555-574.

Heywood, I., Cornelius, S. \& Carver, S. (2006). An Introduction to Geographical Information Systems. Third edition. Pearson Education Limited, Essex.

Karlsdóttir, A., Randall, L., \& G. Norlén (2018). Towards Inclusive Nordic Labour Markets. In Grunfelder, J., Rispling, L., \& Norlén, G. (Eds.), State of the Nordic Region 2018 (pp. 74-86). Nordic Council of Ministers.

Kotilainen, J., Eisto, I. \& Vatanen, E. (2015). Uncovering Mechanisms for Resilience: Strategies to Counter Shrinkage in a Peripheral City in Finland. European Planning Studies, 23:1, 53-68.

Market Profiles (2017). Statistics Sweden's Market Profiles - product catalogue 2017.
Statistics Sweden. <https://www.scb.se/con tentassets/2ce41d60bac84a4c9ba1d86f8dfb 242a/product-catalogue-2017.pdf> (accessed 20.12.2018)

Population Grids (2018). Eurostat Statistics Explained - Population Grids. Eurostat. <https://ec.europa.eu/eurostat/statisticsexplained/index.php/Population_grids\#Grid_ statistics> (accessed 20.12.2018)

Sánchez Gassen, N. (2018) Population Growth and Ageing: Past, present and future trends. In Grunfelder, J., Rispling, L., \& Norlén, G. (Eds.), State of the Nordic Region 2018 (pp. 24-34). Nordic Council of Ministers.

Servillo L., Atkinson R., Smith I., Russo A., Sýkora L., Demazière C. \& Hamdouch A. (2014). TOWN, small and medium sized towns in their functional territorial context, Final Report, Espon, Luxembourg.

Servillo, L., Atkinson, R. \& Hamdouch, A. (2017). Small and medium-sized towns in Europe: Conceptual, methodological and policy issues. Tijdschrift Voor Economische En Sociale Geografie, 108(4), 365-379.

Smas, L. (2018). Urbanisation: Nordic geographies of urbanisation. In Grunfelder, J., Rispling, L., \& Norlén, G. (Eds.), State of the Nordic Region 2018 (pp. 36-46). Nordic Council of Ministers.

Smeds, H. \& Mattila, J. (1941). Om utvecklingen av tätorter och landsbygd i Finland 1880-1930. En befolkningsgeografiskstudie. Geografiska Annaler, Vol. 23 (1941), pp. 210-238.

Sporrong, U. (2008). Features of Nordic Physical Landscapes: Regional Characteristics. In Jones, M. \& Olwig, K.R. (Eds.) Nordic Landscapes: Region and Belonging on the Northern Edge of Europe. Minneapolis: University of Minnesota Press.

Statistics Finland (2007) Väestönkehitys itsenäisessä Suomessa - kasvun vuosikymmenistä kohti harmaantuvaa Suomea. <http://www.stat.fi/tup/suomi9o/ joulukuu.html> (accessed 20.12.2018)

Tunström, M. Lidmo, J. \& Bogason, Á. (2018). The compact city of the north - functions, challenges and planning strategies. Nordregio Report 2018:4. Stockholm, Nordregio. 


\section{Appendix Tables}

\begin{tabular}{|l|c|c|c|c|}
\hline Denmark & $\begin{array}{c}\text { Growing } \\
\text { grids }\end{array}$ & $\begin{array}{c}\text { Shrinking } \\
\text { grids }\end{array}$ & $\begin{array}{c}\text { Stable } \\
\text { grids }\end{array}$ & $\begin{array}{c}\text { Highly } \\
\text { sparse grids }\end{array}$ \\
\hline $\begin{array}{l}\text { Significantly growing municipalities (relative } \\
\text { population increase of 5\% or more) }\end{array}$ & $46.0 \%$ & $42.9 \%$ & $7.8 \%$ & $3.3 \%$ \\
\hline $\begin{array}{l}\text { Moderately growing municipalities (relative } \\
\text { population increase between 2\% and 5\%) }\end{array}$ & $38.3 \%$ & $49.7 \%$ & $8.0 \%$ & $3.9 \%$ \\
\hline $\begin{array}{l}\text { Stable municipalities (relative population } \\
\text { change between -2\% and 2\%) }\end{array}$ & $34.8 \%$ & $52.0 \%$ & $8.6 \%$ & $4.6 \%$ \\
\hline $\begin{array}{l}\text { Moderately shrinking municipalities (relative } \\
\text { population decrease between 2\% and 5\%) }\end{array}$ & $29.7 \%$ & $56.9 \%$ & $8.3 \%$ & $5.1 \%$ \\
\hline $\begin{array}{l}\text { Significantly shrinking municipalities (relative } \\
\text { population decrease of 5\% or more) }\end{array}$ & $22.3 \%$ & $61.9 \%$ & $8.8 \%$ & $7.1 \%$ \\
\hline
\end{tabular}

\begin{tabular}{|l|c|c|c|c|}
\hline Finland & $\begin{array}{c}\text { Growing } \\
\text { grids }\end{array}$ & $\begin{array}{c}\text { Shrinking } \\
\text { grids }\end{array}$ & $\begin{array}{c}\text { Stable } \\
\text { grids }\end{array}$ & $\begin{array}{c}\text { Highly } \\
\text { sparse grids }\end{array}$ \\
\hline $\begin{array}{l}\text { Significantly growing municipalities (relative } \\
\text { population increase of 5\% or more) }\end{array}$ & $36.3 \%$ & $40.1 \%$ & $8.4 \%$ & $15.2 \%$ \\
\hline $\begin{array}{l}\text { Moderately growing municipalities (relative } \\
\text { population increase between 2\% and 5\%) }\end{array}$ & $34.3 \%$ & $42.8 \%$ & $9.3 \%$ & $13.7 \%$ \\
\hline $\begin{array}{l}\text { Stable municipalities (relative population } \\
\text { change between -2\% and 2\%) }\end{array}$ & $28.5 \%$ & $43.4 \%$ & $9.7 \%$ & $18.3 \%$ \\
\hline $\begin{array}{l}\text { Moderately shrinking municipalities (relative } \\
\text { population decrease between 2\% and 5\%) }\end{array}$ & $25.8 \%$ & $44.4 \%$ & $9.8 \%$ & $20.0 \%$ \\
\hline $\begin{array}{l}\text { Significantly shrinking municipalities (relative } \\
\text { population decrease of 5\% or more) }\end{array}$ & $18.5 \%$ & $45.8 \%$ & $9.8 \%$ & $25.9 \%$ \\
\hline
\end{tabular}

\begin{tabular}{|l|c|c|c|c|}
\hline Norway & $\begin{array}{c}\text { Growing } \\
\text { grids }\end{array}$ & $\begin{array}{c}\text { Shrinking } \\
\text { grids }\end{array}$ & $\begin{array}{c}\text { Stable } \\
\text { grids }\end{array}$ & $\begin{array}{c}\text { Highly } \\
\text { sparse grids }\end{array}$ \\
\hline $\begin{array}{l}\text { Significantly growing municipalities (relative } \\
\text { population increase of 5\% or more) }\end{array}$ & $46.9 \%$ & $36.9 \%$ & $7.2 \%$ & $9.1 \%$ \\
\hline $\begin{array}{l}\text { Moderately growing municipalities (relative } \\
\text { population increase between 2\% and 5\%) }\end{array}$ & $36.4 \%$ & $41.9 \%$ & $7.3 \%$ & $14.4 \%$ \\
\hline $\begin{array}{l}\text { Stable municipalities (relative population } \\
\text { change between -2\% and 2\%) }\end{array}$ & $34.1 \%$ & $43.6 \%$ & $8.1 \%$ & $14.3 \%$ \\
\hline $\begin{array}{l}\text { Moderately shrinking municipalities (relative } \\
\text { population decrease between 2\% and 5\%) }\end{array}$ & $29.1 \%$ & $44.0 \%$ & $8.3 \%$ & $18.5 \%$ \\
\hline $\begin{array}{l}\text { Significantly shrinking municipalities (relative } \\
\text { population decrease of 5\% or more) }\end{array}$ & $26.8 \%$ & $47.2 \%$ & $8.2 \%$ & $17.9 \%$ \\
\hline
\end{tabular}




\begin{tabular}{|c|c|c|c|c|}
\hline Sweden & $\begin{array}{l}\text { Growing } \\
\text { grids }\end{array}$ & $\begin{array}{l}\text { Shrinking } \\
\text { grids }\end{array}$ & $\begin{array}{l}\text { Stable } \\
\text { grids }\end{array}$ & $\begin{array}{l}\text { Highly } \\
\text { sparse grids }\end{array}$ \\
\hline $\begin{array}{l}\text { Significantly growing municipalities (relative } \\
\text { population increase of } 5 \% \text { or more) }\end{array}$ & $50.6 \%$ & $36.3 \%$ & $6.5 \%$ & $6.6 \%$ \\
\hline $\begin{array}{l}\text { Moderately growing municipalities (relative } \\
\text { population increase between } 2 \% \text { and } 5 \% \text { ) }\end{array}$ & $42.5 \%$ & $40.0 \%$ & $8.0 \%$ & $9.5 \%$ \\
\hline $\begin{array}{l}\text { Stable municipalities (relative population } \\
\text { change between }-2 \% \text { and } 2 \% \text { ) }\end{array}$ & $39.7 \%$ & $41.4 \%$ & $7.6 \%$ & $11.4 \%$ \\
\hline $\begin{array}{l}\text { Moderately shrinking municipalities (relative } \\
\text { population decrease between } 2 \% \text { and } 5 \% \text { ) }\end{array}$ & $35.5 \%$ & $40.3 \%$ & $7.0 \%$ & $17.3 \%$ \\
\hline $\begin{array}{l}\text { Significantly shrinking municipalities (relative } \\
\text { population decrease of } 5 \% \text { or more) }\end{array}$ & $32.7 \%$ & $40.9 \%$ & $6.8 \%$ & $19.6 \%$ \\
\hline
\end{tabular}





\section{(1I) Nordregio}

P.O. Box 1658

SE-111 86 Stockholm, Sweden

nordregio@nordregio.org

www.nordregio.org

www.norden.org 